$1-1-1964$

\title{
Towards solving the low-income problem of small farmers in the Appalachian area
}

Anthony L. Pavlick

Follow this and additional works at: https://researchrepository.wvu.edu/ wv_agricultural_and_forestry_experiment_station_bulletins

\section{Digital Commons Citation}

Pavlick, Anthony L., "Towards solving the low-income problem of small farmers in the Appalachian area" (1964). West Virginia Agricultural and Forestry Experiment Station Bulletins. 499.

https://researchrepository.wvu.edu/wv_agricultural_and_forestry_experiment_station_bulletins/465 @ WVU. It has been accepted for inclusion in West Virginia Agricultural and Forestry Experiment Station Bulletins by an authorized administrator of The Research Repository @WVU. For more information, please contact ian.harmon@mail.wvu.edu. 




\section{Towards Solving \\ The Low-Income Problem \\ Of Small Farmers in the Appalachian Area}

ANTHONY L. PAVLICK

Interregional Publication For The State Agricultural Experiment Stations

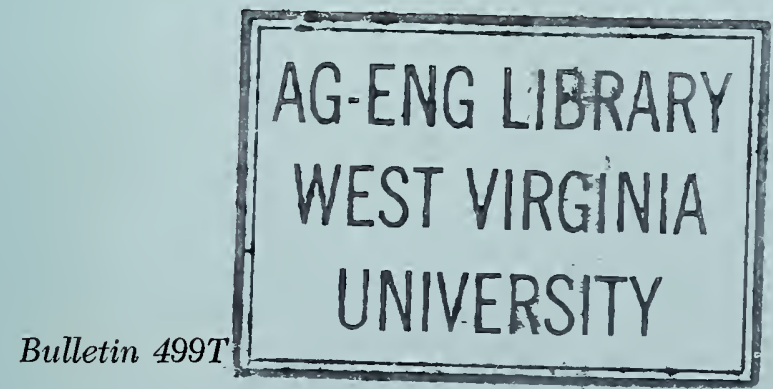

West Virginia University Agricultural Experiment Station 


\section{Members of the Technical Committee}

H. G. Halcrow, Illinois Agricultural Experiment Station

J. B. Hassler, Nebraska Agricultural Experiment Station

D. E. Hathaway, Michigan Agricultural Experiment Station

${ }^{*}$ S. S. Hoos, California Agricultural Experiment Station

E. L. Menzie, Arizona Agricultural Experiment Station

${ }^{*}$ D. Paarlberg, Indiana Agricultural Experiment Station

${ }^{*}$ K. L. Robinson, New York Agricultural Experiment Station

${ }^{*}$ R. IV. Rudd, ${ }^{1}$ Kentucky Agricultural Experiment Station

G. S. Tolley, North Carolina Agricultural Experiment Station

L. G. Tweeten, Oklahoma Agricultural Experiment Station

B. S. White, Cooperative State Research Service, U.S.D.A.

L. W. Witt, Michigan Agricultural Experiment Station

\section{Members of Administrative Advisory Committee}

G. F. Dow (Northeast), Maine Agricultural Experiment Station

R. E. Huffman (West), Montana Agricultural Experiment Station

W. A. Seay (South), Kentucky Agricultural Experiment Station

C. P. Wilson² (North Central), Kansas Agricultural Experiment Station

* Members of Executive Committee

1 Chairman of Technical Committee

2 Interregional Administrative Adviser

West VIRGINIA UNIVERSITY

Agricultural Experiment Station

College of Agriculture, Forestry, and Home Economics

A. H. Vanlandingham, Director

Morgantown 


\section{Towards Solving The Low-Income Problem Of Small Farmers in the Appalachian Area}

ANTHONY L. PAVLICK

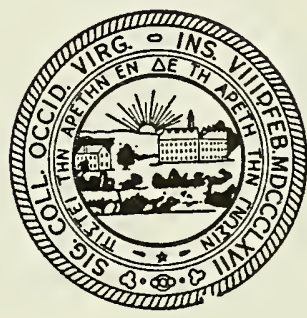

West Virginia University Agricultural Experiment Station 


\section{Contents}

PREFACE

SUMMARY

INCOMES AND LIVING LEVELS OF APPALACHIAN FARMERS

1. Income of Appalachian Farmers _.__ 10

2. Living Levels of Appalachian Farmers ._____ 11

EFFECTS OF FEDERAL FARM PROGRAMS ON INCOMES OF APPALACHIAN FARMERS

1. Direct Effects of Farm Programs on Appalachian

Farm Incomes

2. Indirect Effects of Federal Farm Programs on Appalachian

Farm Incomes

OBSTACLES TO ENLARGEMENT OF APPALACHIAN FARMS

1. Land Resources

2. Human Resources ...______ 25

PROGRAMS FOR APPALACHIAN FARMERS

1. Need for Income Programs _-_ 27

2. Programs _._____________ 31

A. Forest Improvement Projects ________ 31

(1) Benefits _.__________ 32

(2) Costs _________ 38

(3) Program Acceptance _________ 40

(4) Land Suited to Forestry _.____ 42

B. Labor Retraining and Outmigration _.__ 42

C. Increased Welfare for the Disabled and the Retired 42

D. Improved Educational System for School-Age Youth 43

APPENDIX 


\section{Preface}

This publication deals with a particularly important and timely problem. Unemployment, under-employment, low incomes, and poverty are matters of public concern which have recently received renewed emphasis. Among the groups generally recognized as having extremely low incomes are the small Appalachian farmers.

The study reported here documents and quantifies the magnitude of the low-income problem among the small farmers of the Appalachian area. It evaluates the effectiveness of certain policies and programs of the past in dealing with the problem. The analysis reveals that price support, soil bank, and conservation programs of the past have been singularly ineffective in solving or relieving the low-income problem of this area. Alternative public policies for dealing with the problem are suggested.

This study, conducted by the West Virginia University Agricultural Experiment Station, is a part of the Interregional Research project entitled, "Impacts of Present and Proposed Agricultural Price and Income Programs." It is an important contribution to our knowledge about a serious and persistent problem that deserves attention.

C. Peaurs WiLson

Administrative Adviser 
Digitized by the Internet Archive in 2010 with funding from

Lyrasis Members and Sloan Foundation 


\section{Summary}

This report assesses the economic position of Appalachian farmers relative to other farmers, estimates the value of commercial farm programs to Appalachian farmers, and suggests programs in lieu of commercial farm programs which might bring incomes of Appalachian farmers up to par with other farmers.

The study had four objectives: to estimate incomes and living levels of Appalachian farmers and to compare them with those of U.S. farmers generally; to estimate the effects of commercial programs on Appalachian farm incomes; to evaluate the prospects for Appalachian farmers to achieve satisfactory incomes from farming with the help of commercial programs; and to draw policy conclusions for income improvement for these farmers.

Income estimates made in this study for the years 1956-1958 suggest that Appalachian farmers do earn less on the average than other U. S. farmers. Average income of typically Appalachian West Virginia farmers was less than that of U. S. commercial farmers and all farmers by more than $\$ 500$ in two of the years under study and by more than $\$ 1,000$ in the third year. Estimates of living levels of Appalachian farmers, made by means of a formula developed in this study and by using 1954 census data, indicate that Appalachian farmers do live at lower levels than other U. S. farmers. Almost two-thirds of the Appalachian counties fell into the lowest one-fifth of all U. S. counties and most of the remaining fell into the next lowest one-fifth.

Analysis of the effects of federal programs on Appalachian farm income indicates that they are positive but small. Only one-third or less of the Appalachian farmers participated directly in the Price Support, the Soil Bank, and the Conservation Program in 1957-58. Direct payment per Appalachian farmer amounted to less than $\$ 45.00$. Indirect effects were estimated to average not more than $\$ 120$ annually per Appalachian farmer for the years 1954-58.

Analysis of land resources in West Virginia and human resources on small West Virginia farms suggests that there is little prospect for small Appalachian farmers to achieve satisfactory incomes from farming because small farms cannot be enlarged to commercial size. When farms were hypothetically enlarged to several times their present average size by adding land, most did not provide minimum land resources for a commercial operation. More than one-half of the low-income farmers on small farms could not meet the labor requirement of a commercial farm because of old age or other disability. The remainder were not willing to consider farm enlargement. 
Because opportunities for significant income improvement in agriculture are extremely limited for small Appalachian farmers, four nonfarm programs are suggested: a forest improvement program, a retraining and outmigration program, increased welfare to the needy, and an improved educational system for school-age youth. Crude cost-benefits estimates for forest improvement in West Virginia suggest that such projects could provide employment for all underemployed able-bodied farm operators in the project area up to their retirement, provide some supplementary income to most retired and disabled operators through proceeds from the sale of land, take land permanently out of agriculture, and perhaps yield a positive return on the total project investment.

Job retraining programs for unemployed adults should include job placement wherever possible, particularly when employment opportunities are outside the area. Since young people will need to migrate to find employment for some time to come, the quality of public education in the Appalachian region should be improved to at least meet national norms. This will require federal aid. General education and nonfarm vocational training should be emphasized, and training in vocational agriculture in most areas should be reoriented in the direction of greatest employment potential.

The conclusions suggest some further areas of research. Since crude cost-benefits estimates indicate that a forest improvement program may be a feasible solution to the low-income problem for the present generation of farmers, it may be well to study this solution further. A comprehensive study of forestry prospects for the area, in a single and multiple-use context, including long-run demand-supply estimates as a basis for more precise cost-benefits estimates, is envisaged.

Retraining programs for the technologically unemployed and vocational training for in-school and out-of-school youth presuppose employment upon completion of training. In light of the present structural unemployment in the economy and the rate of technological advance, research might well be undertaken to determine future manpower needs, insofar as this is possible, so that training and retraining programs can be tailored to these needs. 


\section{Towards Solving the Low-Income Problem Of Small Farmers in the Appalachian Area}

\section{Anthony L. Pavlick*}

THERE are two types of income problems in agriculture-those due to low prices relative to costs and those due to low productivity. Programs to increase prices can deal with the price problem and hence the income problem of commercial farmers. But these programs cannot solve the income problem of noncommercial farmers because these farmers do not produce in volume. Noncommercial farmers can profit from commercial programs only if their production is increased substantially, thus enabling them to make a significant market contribution.

The income problem for most Appalachian farmers is one of low productivity associated with limited resources. Appalachian farms are small and farm income is low. Appalachian farmers do supplement their farm incomes to some extent by income from off-farm work and from other nonfarm sources.

It is generally believed that Appalachian farmers are among the most poverty-stricken of American farmers. It has been stated that Appalachian farmers benefit little, if at all, from commercial programs. The first belief has been partially documented; the second not documented at all.

An important question regarding further attempts to solve the farm income problem is "Can Appalachian farmers benefit from future commercial programs?" If they cannot benefit, equity considerations may require that programs better tailored to this group be examined.

This study had four objectives: first, to estimate incomes and living levels of Appalachian farmers and to compare them with those of U. S. farmers generally; second, to estimate the effects of commercial programs on Appalachian farm incomes; third, to evaluate the prospects for Appalachian farmers to achieve satisfactory incomes from farming, with the help of commercial programs; and fourth, to draw some policy conclusions for income improvement for these farmers.

The Appalachian area is a broad sweep of generally hilly and mountainous land parallel to the Atlantic Coast. Within this area lie West Virginia, parts of Pennsylvania, Ohio, Maryland, Kentucky, North Carolina, South Carolina, Tennessee, Georgia, and Alabama. The study

* Anthony L. Pavlick, during the period of this study, was Research Associate, Department of Agricultural Economics, West Virginia University. He is now with the Resources Development Economics Division, U. S. Department of Agriculture, stationed at West Virginia University.

The author gratefully acknowledges all individuals and organizations who assisted the project. Special thanks are due Homer C. Evans and the late W. W. Armentrout. The author, of course, assumes sole responsibility for all material presented. 


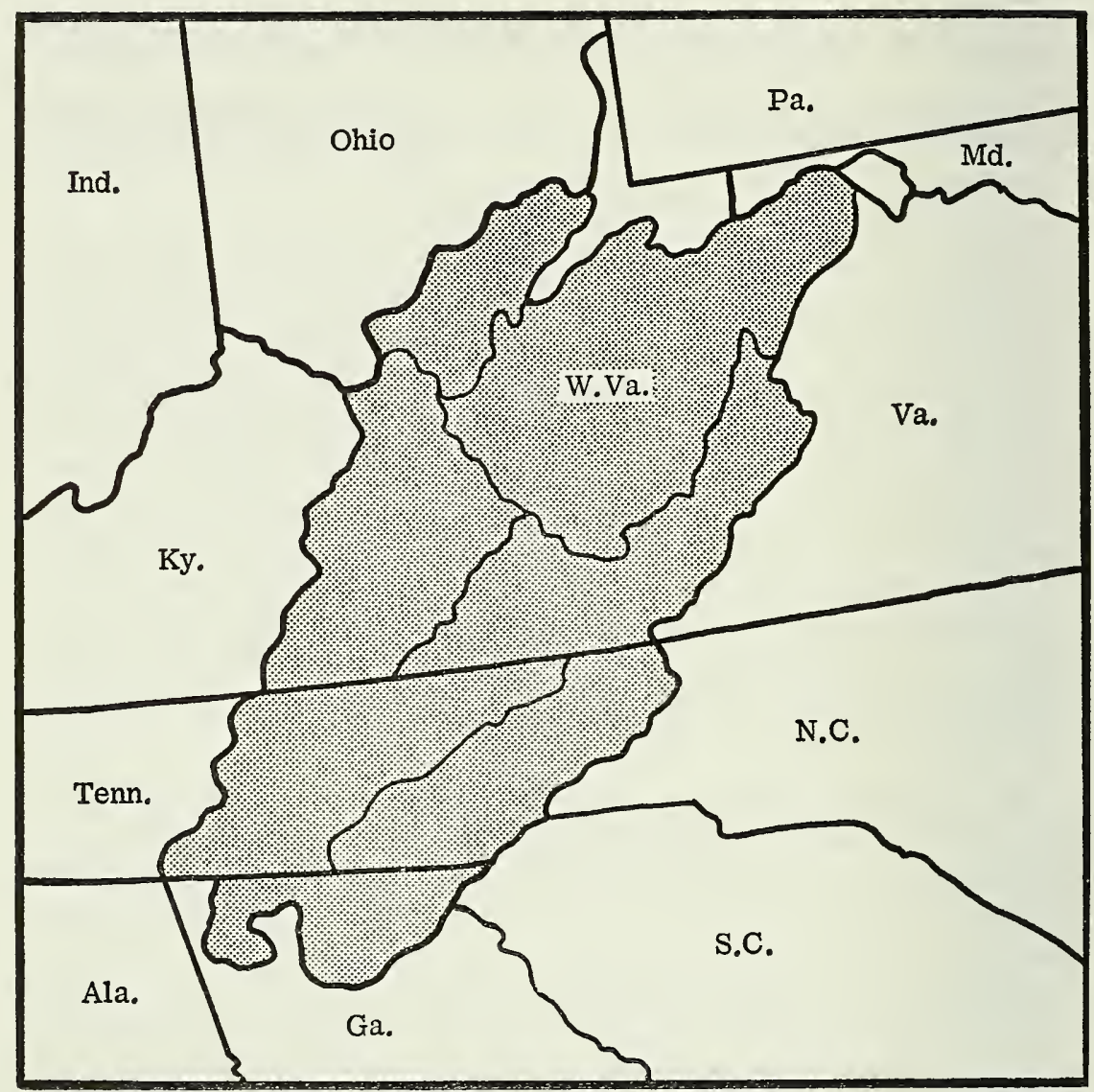

\section{FIGURE 1. The Study Area}

area included 181 contiguous counties in Virginia, West Virginia, Ohio, Kentucky, Tennessee, North Carolina, and Georgia (Figure 1). These counties made up 27 state economic areas' and five economic subregions, ${ }^{2}$ as defined by the Census Bureau. Because the defined area is a sub-set of the physiographic area, and in fact encompasses most of it, conclusions drawn should be generally valid for the entire area.

The study area is about 400 miles long and 200 miles wide. It contains 75,000 square miles, one-half of which are in farms. There were about 320,000 farms in the area in 1954.

1 Donald J. Bogue, State Economic Areas: A Description of the Procedure Used in Making a Functional Grouping of the Counties of the United States, U. S. Bureau of the Census (Washington: Government Printing Office, 1951).

2 Donald J. Bogue and Calvin L. Beale, Farm Population, Economic Subregions of the United States, U. S. Bureau of the Census, Series Census-BAE, No. 19 (Washington: Government Printing Office, 1953). 
The definition and classification of farms and farm operators were those used by the Census of Agriculture for $1954 .^{3}$ The definition includes part-time and residential farms as well as commercial farms. Part-time and residential farmers are included because a large number of these farmers in the Appalachian area derive a substantial part of their total income from farming. This dependence upon farming is in rather sharp contrast to that of part-time and residential farmers in many parts of the United States where such farms are primarily places of residence.

\section{Incomes and Living Levels Of Appalachian Farmers}

Many studies provide evidence that Appalachian farmers earn less and live at lower economic levels than other farmers. Strand, Heady, and Seagraves found that Appalachian commercial farmers earn less from farming than other commercial farmers. ${ }^{4}$ They estimated that in 1949 U. S. commercial farmers earned a $\$ 1,300$ return to capital and a $\$ 1,400$ return to labor, while Appalachian commercial farmers earned $\$ 800$ for capital and $\$ 500$ for labor. Grove found that, generally speaking, income for U. S. farmers varied directly with size of farm as measured by farm sales. ${ }^{5}$ Assuming that income by economic class of farm does not vary between United States and Appalachian farmers, in 1949 the U.S. farmers averaged $\$ 3,300$ while Appalachian farmers averaged $\$ 2,500$.

The "farm-operator family level-of-living index," a statistical measure developed by workers in the U. S. Department of Agriculture, yields evidence that Appalachian farmers live at lower economic levels than other farmers. ${ }^{6}$ In 1954 the level of living index score was 140 for

3 Places of threc or more acres were counted as farms if the annual value of agricultural products, exclusive of home-garden products, amounted to $\$ 150$ or more. The agricultural products could have been either for home use or for sale. Places of less than three acres were counted as farms only if the annual value of sales of agricuitural products amounted to $\$ 150$ or more. Places for which the value of agricultural products for 1954 was less than these minima because of crop failure or other unusual conditions, and places operated at the time of the survey for the first time were counted as farms if normally they could be expected to produce these minimum quantities of agricultural products.

A "farm operator" is a person who operates a farm, either performing the labor himself or directly supervising it. He may be an owner, a hired manager, or a tenant, renter, or sharecropper. If he rents land to others or has land cropped for him by others, he is listed as the operator of only that land which he retains. In the case of a partnership, only one partner was included as the operator. The number of farm operators is considered the same as the number of farms.

4 Edwin G. Strand, Earl O. Heady, and James A. Seagraves, Productivity of Resources Used on Commercial Farms, U. S. Department of Agriculture in cooperation with Iowa Agricultural Experiment Station, Technical Bulletin No. 1128 (Washington: Government Printing Office, 1955) pp. 27-30.

5 Ernest W. Grove, "Per Capita Income by Economic Class of Farm, 1949," Agrlculiural Economics Research, VIII No. 2 (April, 1956) p. 53.

6 Margaret Jarman Hagood, Gladys K. Bowles, and Robert R. Mount, Farm-Operator Family Level-of-Living Indexes for Counties of the United States, 1945, 1950 and 1954, Agricultural Marketing Service, U. S. Department of Agriculture, Statistical Bulletin No. 204 (Washington: Government Printing Office, 1957) pp. 24-78. 
U.S. farmers and 90 for Appalachian farmers. ${ }^{7}$ When Appalachian counties are distributed among U.S. counties according to farm-operator family level-of-living indexes, almost two-thirds fall in the lowest onefifth of all counties and one-third fall in the next lowest one-fifth.

The U. S. Department of Agriculture report, Development of Agriculture's Human Resources, uses the findings of two studies cited above, plus a third to provide the most comprehensive evidence of low income and low living levels of Appalachian farmers. ${ }^{\circ}$ Three criteria are employed to identify the geographic areas of low income and low living levels and to evaluate the seriousness of this problem: (1) average return of less than $\$ 1,000$ to commercial farm operators and their families for their labor and for their capital equity in the farm and equipment, provided the level-of-living index in the area was below the average for the region and one-fourth or more of its commercial farms were low production farms; (2) a level-of-living index in the lowest one-fifth of the nation; and (3) low production farms comprised one-half or more of the commercial farms. If an area met all three criteria, the problem was considered "serious," it it met two, "substantial," and one, "moderate." Under this classification system most of the Appalachian area fell into the "serious" category. No Appalachian county escaped identification as a problem area.

\section{Income of Appalachian Farmers}

In this section estimates of income from all sources for West Virginia farmers were made in an attempt to provide a firmer base for conclusions for comparing incomes of Appalachian farmers than is provided by the studies cited. West Virginia farmers are believed to be representative of Appalachian farmers because important income-determining factors-gross farm sales, off-farm work by operator, and age of operator-of the two groups have similar distributions (Appendix Table 1).

Income was defined to include the annual return to the farm operator and his family for their labor and the return on the operator's capital equity in the farm business; it includes annual income to the operator and members of his family from off-farm employment, nonfarm investments, and transfer payments.

Estimates were made for the years 1956-58. Estimates of the nonfarm income component for West Virginia farmers are based on data

7 Since census data for 1945 were used to construct the index formula, the index for the United States for that year was set equal to 100. By 1954 this index had risen to 140 for U. S. farmers, while for Appalachian farmers it had not yet attained 100, the level enjoyed by $U$. $S$. farmers in 1945.

8 U. S. Department of Agriculture, Development of Agriculture's Human Resources, A Report of Low-Income Farmers (Washington: Government Printing Office, 1955) 44 pp. 
collected in a 1957 survey of 757 farm operators and a 1959 survey of 469 farm operators. Estimates of income from farming are those published by the U. S. Department of Agriculture.' Estimates of income to U. S. commercial farmers and to all farmers were made from data published by the U.S. Department of Agriculture (the income estimating procedures are given in Appendix Tables 2-4).

The findings substantiate the general belief about incomes of Appalachian farmers. In each of the three years studied, average income of West Virginia farmers lagged behind that of all U. S. farmers and U. S. commercial farmers (Table 1). In 1956 and 1957 the income gap between West Virginia farmers and other farmers was more than $\$ 500$; in 1958 the gap was more than $\$ 1,000$.

TABLE 1. Average Income of West Virginia Farmers, All Farmers and Commercial Farmers, United States, 1956-58

\begin{tabular}{l|r|r|r}
\multicolumn{1}{c|}{ Description } & \multicolumn{1}{c|}{1956} & \multicolumn{1}{c|}{1957} & \multicolumn{1}{c}{1958} \\
\hline West Virginia farmers & $\$ 3,111$ & $\$ 2,961$ & $\$ 3,163$ \\
All farmers & 3,686 & 3,785 & 4,300 \\
Commercial farmers & 3,763 & 3,593 & 4,616 \\
\hline
\end{tabular}

a The income estimating procedures are recorded in Appendix Tables 2-4.

\section{Living Levels of Appalachian Farmers}

In this section living levels of Appalachian and all U. S. farmers were estimated and compared by means of an index designed to avoid a bias thought to be inherent in the U. S. Department of Agriculture's farm-operator family level-of-living index when applied to Appalachian farmers. In that index one of the four items is "average value of products sold or traded, in hundreds of dollars." Since Appalachian farmers earn less than one-half of their incomes from farming and U.S. farmers earn two-thirds of their incomes from this source, ${ }^{10}$ this index would appear to bias level-of-living scores for Appalachian farmers downward relative to scores of other farmers. To avoid bias a "modified" index was constructed which did not include this item. This modified index was developed by using the same statistical techniques employed in constructing the U. S. Department of Agriculture's index except that 1954 county census data were used in place of 1945 data."

9 Actually, the estimates of income from farming were adjusted to the open-country nature of the samples in the process of estimating income to West Virginia farmers from all sources (the samples are described in the Appendix).

10 Appendix Tables 2-3.

11 Details of index construction and a comparison of the two are given in the Appendix. 
The modified index formula yields evidence consistent with that provided by the index used by the U. S. Department of Agriculturethat levels of living of Appalachian farmers are lower than those of U. S. farmers. While the United States level-of-living index score was 100 in 1954, the index for the Appalachian area was 57. When Appalachian counties are distributed among U. S. counties according to levelof-living indexes, almost two-thirds fall in the lowest one-fifth of all counties and one-third fall in the next lowest one-fifth.

\section{Effects of Federal Farm Programs On Incomes of Appalachian Farmers}

Programs considered in estimating the effects of federal programs on Appalachian farm incomes are limited to those which affect substantially the money income of farmers in the short run and which are most costly to the federal government: ${ }^{12}$ the Price Support, ${ }^{13}$ the Soil Bank, and the Agricultural Conservation programs. These programs affect incomes directly through payments to farmers and indirectly through governmental activity in the market, which affects the prices of commodities farmers buy and sell.

\section{Direct Effects of Farm Programs}

on Appalachian Farm Incomes

The number and amount of payments made to Appalachian farmers in 1957 and 1958 are estimated in Table 2. Payments under the Price Support Program include unredeemed loans, value of sales made under purchase agreements, value of purchases made by the federal government directly from farmers, and payments made to farmers under the National Wool Act. ${ }^{14}$ Payments under the Soil Bank and Agricultural Conservation programs include rental payments and conservation practice payments.

12 Appendix Table 5.

13 The Price Support Program is only one of a general category of price programs established to stabilize farm prices and incomes, but it is perhaps the only price program important to Appalachian farmers. Other price programs include Section 32, marketing agreement and order programs, the sugar program, the International Wheat Agreement, and special milk programs. (See Harry W. Henderson, Price Programis, Information Division, Commodity Stabilization Service, U. S. Department of Agriculture, Agriculture Information Bulletin No. 135 [Washington: Government Printing Office, 1957] pp. 1-2, 31-47). The Price Support Program differs from other price programs in that under it prices of a number of commodities are supported at some specified dollars and cents minimum, and participating farmers are assured of the support price by the Government through loans, purchases, purchase agreements or payments, depending upon the commodity. The expression "Price Support Program" as used here refers to all programs in which commodity prices are supported at some announced level. Some writers refer to this aggregate of programs as "Price Support Programs."

14 Data on price support operations by commodity in the Appalachian area for 1957 and 1958 are given in Appendix Table 6. 
TABLE 2. Payments Made to Appalachian Farmers Under Price Support, Soil Bank, and Agricultural Conservation Programs, 1957 and $1958^{\mathrm{a}}$

\begin{tabular}{|c|c|c|c|c|c|c|}
\hline \multirow{3}{*}{ Program } & \multicolumn{3}{|c|}{1957} & \multicolumn{3}{|c|}{1958} \\
\hline & \multirow{2}{*}{$\begin{array}{l}\text { Contracts } \\
\text { (Number) }\end{array}$} & \multicolumn{2}{|c|}{ Payments } & \multirow{2}{*}{$\begin{array}{l}\text { Contracts } \\
\text { (Number) }\end{array}$} & \multicolumn{2}{|c|}{ Payments } \\
\hline & & (Total) & $\begin{array}{l}\text { (Aver- } \\
\left.\text { age }^{b}\right)\end{array}$ & & (Total) & $\begin{array}{l}\text { (Aver- } \\
\left.\text { age }^{b}\right)\end{array}$ \\
\hline Price support & 26,293 & $\$ 2,928,929$ & $\$ 111$ & 29,172 & $\$ 3,158,741$ & $\$ 108$ \\
\hline Soil Bank: & & & & & & \\
\hline Acreage Reserve & 12,618 & $2,658,104$ & 211 & 15,135 & $3,485,124$ & 230 \\
\hline Conservation & & & & & & \\
\hline Reserve ….... & 638 & 290,324 & 455 & 1,049 & 562,484 & 536 \\
\hline Conservation & 76,662 & $8,217,828^{c}$ & 107 & 75,107 & $6,992,304^{\mathrm{c}}$ & 93 \\
\hline TOTAL _- & & $\$ 14,095,185$ & & & $\$ 14,198,653$ & \\
\hline
\end{tabular}

a ASC Annual Reports for West Virginia, Virginia, Tennessee, North Carolina, and Georgia; correspondence with state ASC committee for Kentucky and Ohio.

b Appalachian farmers numbered 314,000 in 1957 and 318,000 in 1958 according to Agricultural Stabilization and Conservation Program data.

c These payments include the value of materials delivered in lieu of cash; they also include the cost of soil conservation technical service necessary to some conservation measures.

Appalachian farmers received about $\$ 14$ million in payments in each of the years studied. Roughly one-half this amount was paid under the Agricultural Conservation Program, one-fifth under Price Support, and one-fifth under the Acreage Reserve Program. The Conservation Reserve Program accounted for less than 5 per cent of total payments. ${ }^{15}$

Only a fraction of the farmers were reached by these programs. Only one-fourth of them participated in the Agricultural Conservation Program, less than 10 per cent participated in the Price Support Program, and less than 5 per cent and 1 per cent, respectively, participated in the Acreage Reserve and the Conservation Reserve programs.

Average payments to participating farmers were small. While payments under the Conservation Reserve Program averaged about $\$ 500$, the average under the Acreage Reserve was $\$ 200$, and the averages for the Price Support and the Agricultural Conservation Program were $\$ 100$ each. Since the larger farmers usually hold the larger contracts, and a greater number of contracts per farmer, most of the farmers received less than the average payments for the program in which they participated.

Considering the relatively small payments and the low rate of participation, the direct effect of farm programs on Appalachian farm income is small. If total payments made to participating Appalachian farmers were divided equally among all Appalachian farmers, average payment per farmer would be $\$ 45.00$. This figure, however, would not

15 Participation in the Conservation Reserve was increasing during the period; 1959 payments under this program may well have been in excess of 5 per cent. 
represent an addition to each Appalachian farmer's net income. Part of this income displaces other income that would result without the Price Support and the Soil Bank programs and part of it accrues to cover expenditures that might not be made without the Agricultural Conservation Program. Commodities that move to CCC storage through loans, purchase agreements, or purchases under the Price Support Program would otherwise yield a return in the market; land idled under the Soil Bank Program in exchange for payments would otherwise produce for the market; and payments received by farmers under the Agricultural Conservation Program depend upon conservation expenditures. Thus direct (net) income effects, per Appalachian farmer, amounted to less than $\$ 45.00$.

\section{Indirect Effects of Federal Farm Programs}

\section{On Appalachian Farm Incomes}

Farm programs affect the market prices of commodities that Appalachian farmers handle either as production inputs or outputs. Thus, Appalachian farmers are affected indirectly by farm programs. While all three programs affect commodity prices, only the Price Support and Production Control Program and the Soil Bank Program affect prices in the short run; hence only the effects of these two programs are considered.

Indirect effects are estimated by comparing market derived gross farm incomes under two situations, one with the Price Support and Production Control and the Soil Bank programs and the other without. Gross farm income for the first situation is estimated using recent Appalachian price and production data. Gross farm income in the second situation, under "free market" conditions, is estimated using hypothetical price and production data. Production costs were assumed to remain constant.

Prices of farm commodities would be expected to fall in the short run under free market conditions. ${ }^{16}$ Although no studies have estimated

16 Five studies show that commodity prices would decline under free market conditions: G. E. Brandow, Interrelations Among Demands for Farm Products and Implications for Control of Market Supply, Bulletin 680 (1nterregional Publication for the State Agricultural Experiment Stations), Agricultural Experiment Station, University Park, Pennsylvania, August 1961; Geoffrey Shepherd, Arnold Paulsen, Francis Kutish, Don Kaldor, Richard Heifner and Gene Futrell, Production, Price and Income Estimates and Projections for the Feed-Livestock Economy Under Specified Control and Market-Clearing Conditions, Department of Economics and Sociology, Center for Agricultural and Economic Adjustment, Special Report No. 27, Iowa State University, Ames, Iowa, August 1960; 86th Congress, 2nd Session, Economic Policies for Agriculture in the 1960's, Joint Economic Committee Print, Congress of the United States (Washington: Government Printing Office, 1960) pp. 15-17; 86th Congress, 2nd Session, Report from the U.S. Department of Agriculture and a Statement from the Land Grant Colleges IRM-I Advisory Committee on Farm Price and Income Projections 1969-65 under Conditions Approximating Free Production and Marketing of Agricultural Commodities, Senate Document No. 77, Congress of the United States, (Washington: Government Printing Office, 1960); K. L. Robinson, "Possible Effects of Eliminating Direct Price Support and Acreage Control Programs," Farm Economics, Department of Agricultural Economics, New York State College of Agriculture, Cornell University, Ithaca, New York, Number 218, October 1960, pp. 5813-5820. 
the set of prices that would be generated if Price Support and Production Control and Soil Bank programs were terminated, Brandow has estimated prices that would be obtained under quite similar conditions-that all farm production in 1955-57 had cleared the market. ${ }^{17}$ The major difference between that situation and the one hypothesized here is that production of basic crops was subject to acreage allotments in the Brandow study. Eliminating allotments would increase production of basic commodities and result in greater price declines. Hence, corn, wheat, and cotton prices under free market conditions would be lower than those obtained in the Brandow study. However, since prices of commodities grown in their stead would be higher than his estimates, these errors would tend to cancel when income effects are computed. Brandow's price estimates, shown in Table 3, were assumed to be free market prices for purposes of this study.

While farm prices would decline under free market conditions, Appalachian farm production would probably remain about the same. The Price Support and Production Control Program does not appear to have restricted the production of any basic commodity, burley tobacco excepted, since these commodities are not extensively grown in the area. ${ }^{18}$

Burley acreage allotments do restrict land inputs in the production of that commodity. Hence the production adjustment that might be made if the allotment restriction were lifted is somewhat speculative. Allotments, which average between six-tenths and seven-tenths of an acre, are held by 122,000, or 38 per cent of all Appalachian farmers, and about 90 per cent of the 81,600 allotted acres are harvested. ${ }^{19}$ But because allotments have been so restrictive, burley farmers have substituted other inputs, particularly fertilizer and labor, to an extent that were the land input restriction lifted, the substitution of land for fertilizer and labor might result in only a small production increase. In addition, barn space for housing tobacco may not exceed greatly that required for the crop under allotment conditions, and thus might set limits to any production increase.

17 G. E. Brandow, Interrelations Among Demands for Farm Products and Implications for Control of Market Supply, Bulletin 680, (Interregional Publication for the State Agricultural Experiment Stations), Agricultural Experiment Station, University Park, Pennsylvania, August 1961, pp. 92-95.

18 Corn allotments probably affect only the 700 cash grain farmers in the 11 Appalachian commercial corn-producing counties. If only these farmers found their allotments restricting, and their allotments were one and one-half times the average corn acreage per farm for the county, they could double their corn acreage without causing the average acreage of corn on all Appalachian farms to increase more than one-fourth acre.

Only 4,451 farmers, 1 per cent of all farmers, held cotton allotments in 1958. Although allotments totaled 11,973 acres, only 1,938 acres (16 per cent) were harvested. In that same year 34,716 farmers (11 per cent of all farmers) held wheat allotments totaling 165,702 acres, but they seeded only two-thirds of this acreage.

Rice is not grown in the Appalachian area, only 11 farmers held peanut allotments in 1958, totaling 19 acres; six farmers held fire-cured tobacco allotments, totaling 3 acres; 2,256 farmers, less than 1 per cent of all farmers, held flue-cured tobacco allotments for 3,439 acres, but harvested only 1,899 acres, just 55 per cent of their allotment.

is State ASC reports. 
TABLE 3. Expected Prices of Crops and Livestock if All Crop Supplies Available from Production Had Cleared the Market in $1955-57^{a}$

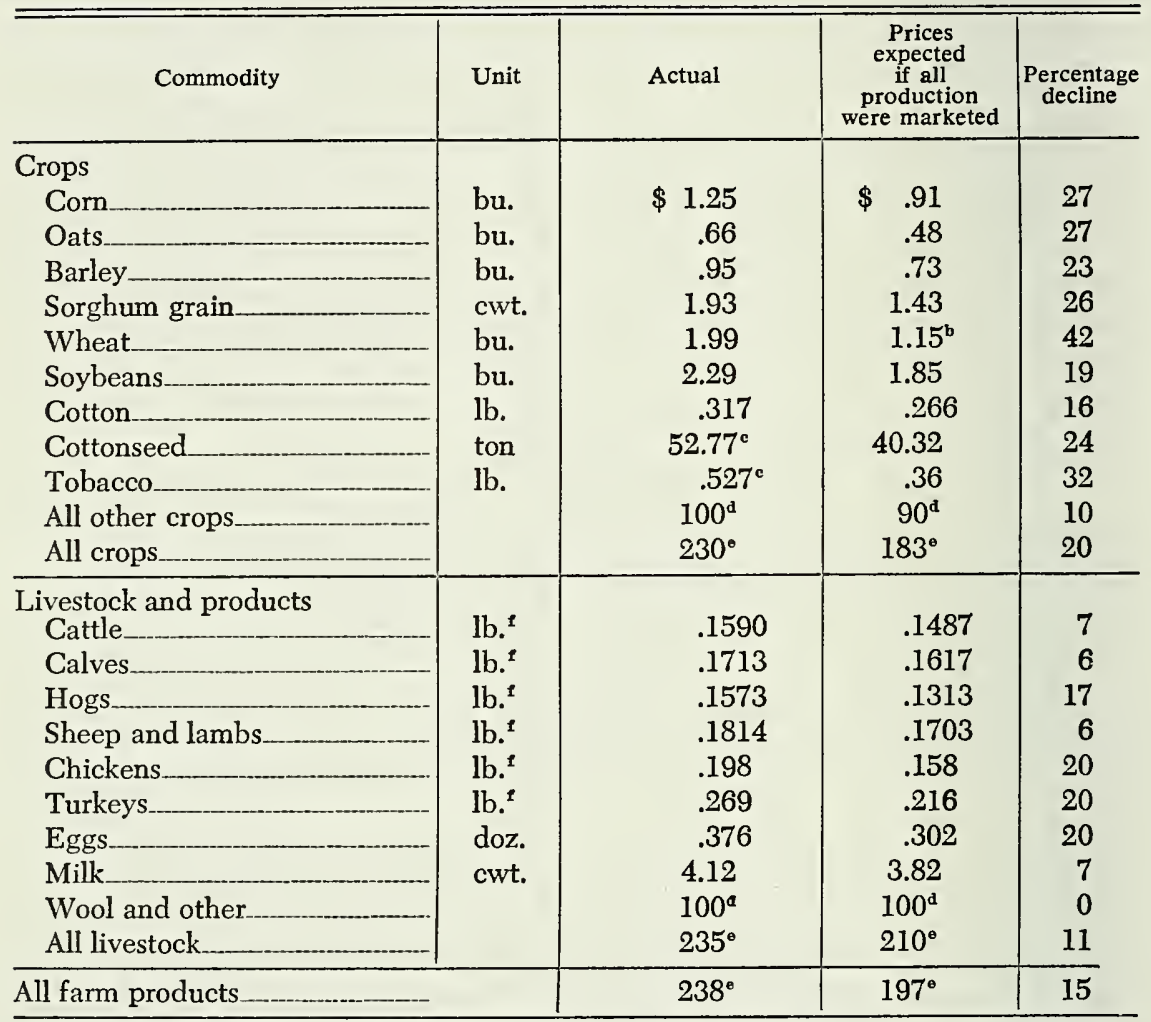

a From Table 18 in Interrelations Among Demands for Farm Products and Implications for Control of Market Supply by G. E. Brandow.

b Feed wheat estimated at $\$ 1.03$, all wheat at $\$ 1.15$.

c 1954-56 crop year average.

d Arbitrary index numbers to indicate assumed price change.

Index of prices received by farmers, 1910-14=100.

Liveweight slaughtered.

The Soil Bank Program has not restricted production to any appreciable extent, because participation has been low. While the program idled 7 per cent of cropland in the United States in the two years under study, in West Virginia it took out less than 1 per cent. ${ }^{20}$ And finally, relative price changes caused by the shift to the free market would not significantly change the input and output mix of Appalachian agriculture. A sizeable part of Appalachian production comes from small farms which do not adjust production to every price change because the difference in income does not warrant it. 
Since the physical input and output of Appalachian agriculture would remain about the same in the two situations, the difference in net income-the indirect effect of programs-is easily calculated. For each commodity whose market price is affected by programs, Appalachian purchases (inputs) are subtracted from sales (output), and this quantity, expressed in dollars (at prices generated under programs), is multiplied by the percentage price decline expected under free market conditions. The product is an estimate of the indirect income effect of programs on that particular commodity. The sum of these products is an estimate of the indirect income effect to Appalachian farmers. These calculations are made in Table 4. They are based for the most part on data from the Agricultural Census for 1954 and the Federal Crop Reporting Service for 1954 and for 1957 and 1958.

The estimates suggest that commercial farm programs yield positive but small indirect income benefits to Appalachian farmers. While total indirect effects were estimated at $\$ 38$ million, this would amount to only $\$ 120$ per farmer per year since there were 320,000 Appalachian farmers in 1954. However, most farmers received less than this amount. Twothirds of the indirect effects accrued to burley growers, who make up just over one-third of all Appalachian farmers. Indirect income benefits to burley growers might average about $\$ 200$ annually per farmer, while benefits to other farmers would average well under $\$ 100$ per year.

Though indirect income benefits are small, this is not to say that they are unimportant to Appalachian farmers, or that Appalachian farmers have not benefited in proportion to their output. The point is that income benefits per farm are low mainly because per farm output is low.

\section{Obstacles to Enlargement Of Appalachian Farms}

Whether or not Appalachian farmers can achieve satisfactory incomes from farming, with the help of commercial programs, depends upon whether it is economically feasible to enlarge these farms to commercial size. Enlarging the farm-by adding land, labor, capital, or management inputs-is often recommended as a means to improve farmers' incomes. It is argued that as farms are enlarged, large-scale low-cost technologies become available; these increase net income by reducing per unit costs and increase the number of units produced. As output increases, income to the farmer from commercial programs also goes up because commercial programs are tied to units of input or output.

It has been argued, however, that Appalachian farm enlargement is economically not feasible because of the poor quality of the land resource 


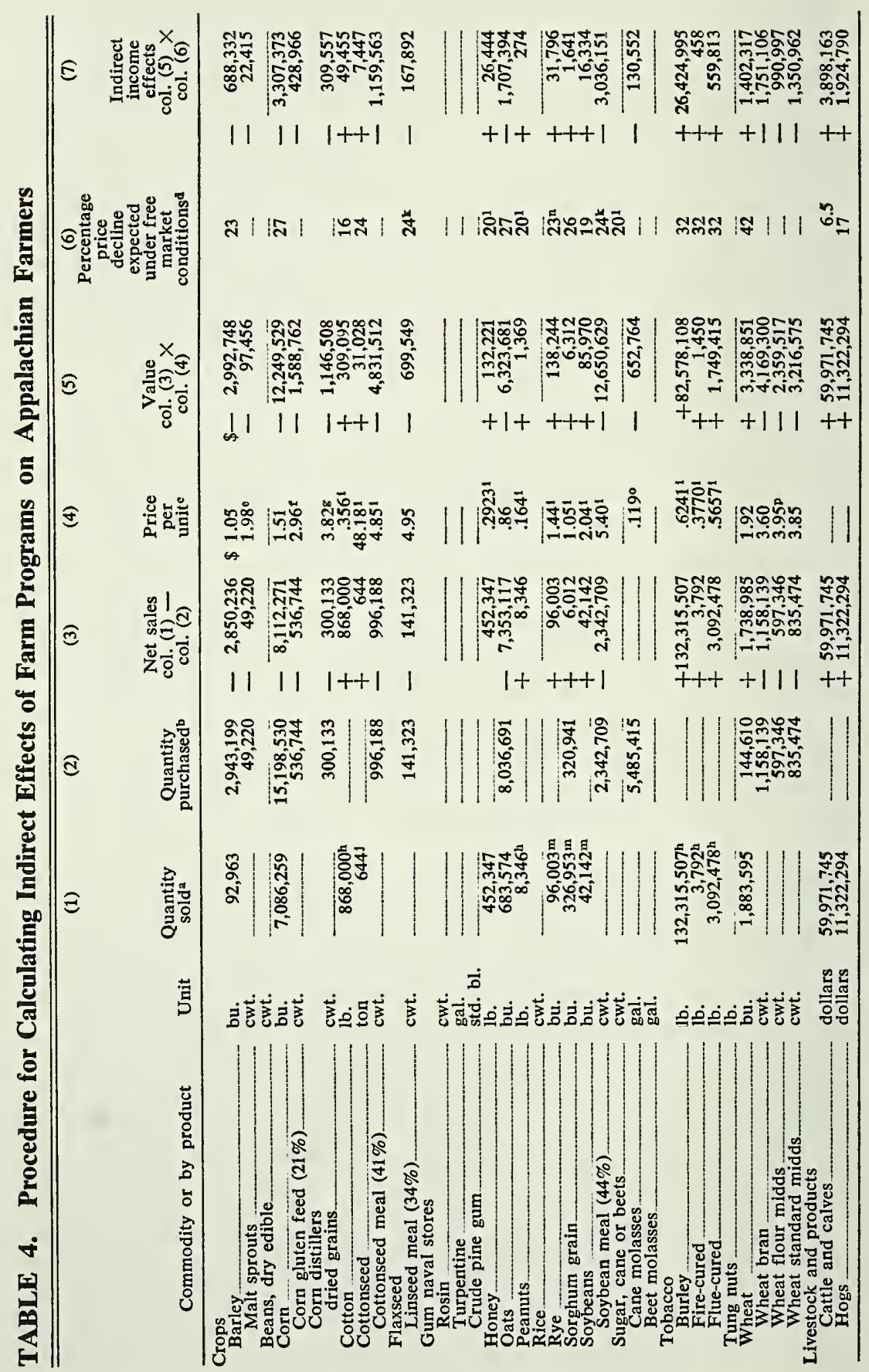




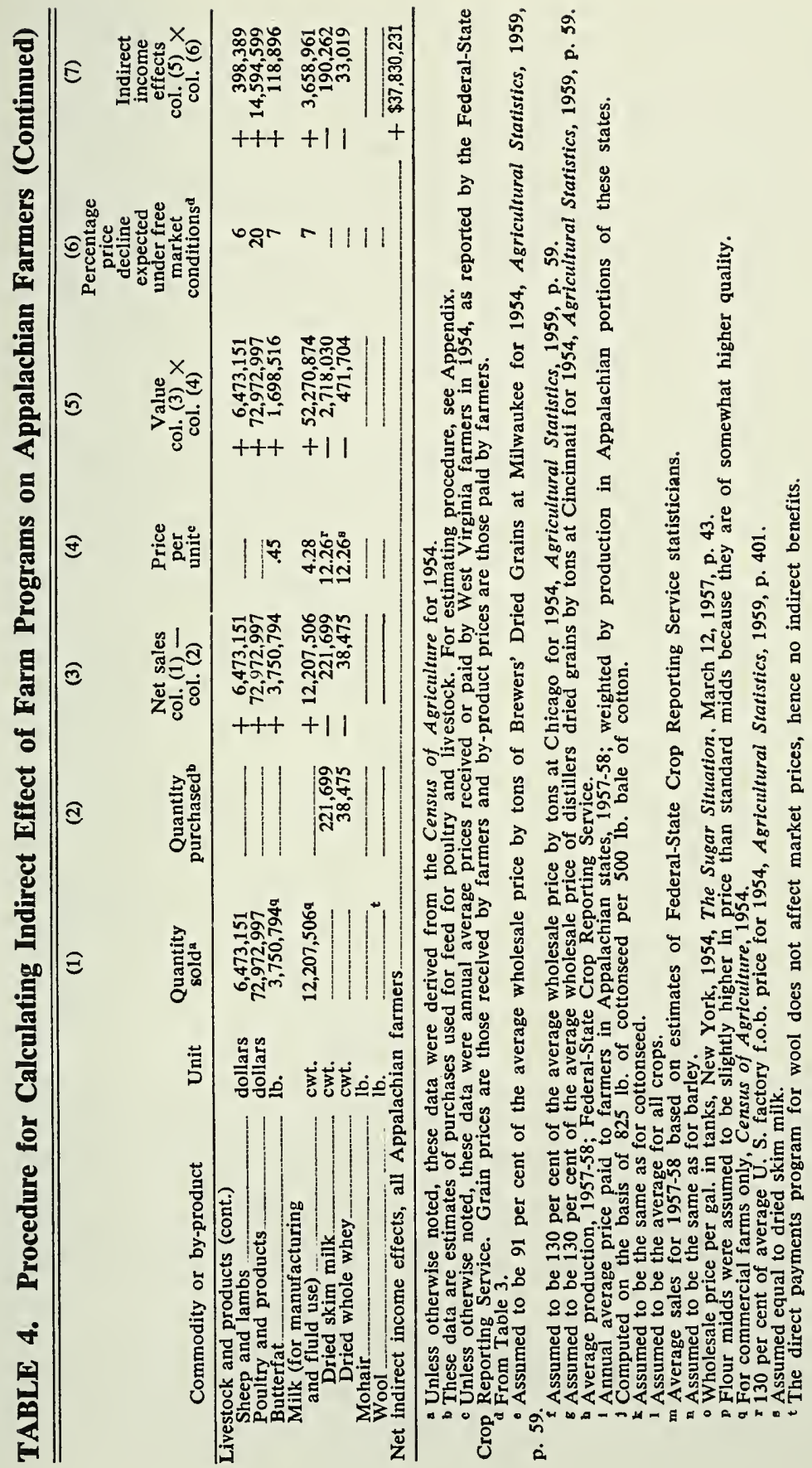


in the area, and because of the nature of the human resource on Appalachian farms. This section reports on an analysis of land and human resources relative to their suitability for commercial farming.

Commercial farming here is taken to mean farming on a scale sufficiently large to provide, with good management, reasonable returns to all factors of production. For most types of farms, this requires annual gross sales of $\$ 10,000$ or more. ${ }^{21}$ If Appalachian farmers are to find a solution to their income problem within agriculture, it must be on this size farm. Units smaller than this cannot compete because they cannot adopt the cost-reducing technologies which through time are becoming more and more oriented toward the larger commercial unit.

\section{Land Resources}

A dairy farm and a beef-sheep farm were selected as economical commercial units for the rough and hilly land of the Appalachian area. ${ }^{22}$ These two units served as standards in the analysis of land resources. The budgeted dairy unit is built around a 35-cow herd. All the forage is produced on the farm and all concentrates are purchased. Forty-six acres of cropland and ninety acres of improved permanent pasture are necessary for the operation. The cows are expected to yield an average of $10,000 \mathrm{lbs}$. of 3.8 per cent milk. The output of this unit consists of milk sold on the Grade B market, cull cows, heifers, and calves. The value of this output at long-term normal prices is $\$ 12,209$.

The budgeted beef-sheep unit is built around a 100-cow beef herd and a 100 -ewe flock. As in the dairy unit, all forage is produced on the farm and needed concentrates are purchased. This unit requires 309 acres of which 110 acres are cropland and 199 acres are permanent pasture. The beef herd is expected to raise a 90 per cent calf crop and the sheep flock a lamb crop of 145 per cent. The output of this unit consists of feeder calves, cull cows, lambs, cull ewes, and wool. The value of this output at long-term normal prices is $\$ 11,278$.

Small Appalachian farms, those grossing less than $\$ 5,000$ annually, have considerably less useable acreage than the hypothesized commercial units require. In West Virginia, small farms averaged 93 acres, with only 22 acres of cropland and 27 acres of pasture land. ${ }^{23}$

To test the feasibility of enlarging farms by adding land, 100 sample West Virginia small farms ${ }^{24}$ were located on Land-Use Capability Maps

21 Harold E. Barnhill, Resource Requirements on Farms for Specified Operator Incomes, Economic Research Service, U. S. Department of Agriculture, Agricultural Economic Report No. 5 (Washington: Government Printing Office, 1962).

22 Budgeted data for these farms are recorded in Appendix Table 7.

23 Census of Agriculture for 1954. In the census 95 per cent of all Appalachian farms were small farms.

24 Sampling procedure is described in the Appendix. 
(furnished by the Soil Conservation Service). Each farm was expanded first to 360 acres, then to 1,000 acres, and useable crop and pasture land in these expanded units was compared with requirements for the commercial dairy unit and the beef-sheep unit. ${ }^{25}$ This procedure assumed that farmers would be willing to expand their farms to 360 acres for a commercial dairy unit and to 1,000 acres for a commercial beef-sheep unit. ${ }^{26}$ Some other assumptions were made to assure reasonable efficiency in the use of the land. ${ }^{27}$

In Figure 2, the crop and pasture land provided by the small farms expanded to 360 acres is compared with the land requirement of the commercial dairy unit. Four-fifths of the expanded units failed to provide sufficient land for the commercial operation. In Figure 3, the crop and pasture land in those units expanded to 1,000 acres is compared with the land requirement for the commercial beef-sheep farm. Again four-fifths of the expanded units failed to provide enough land. The reasons for the high proportion of failures even when farms were expanded to several times their average size are indicated in Table 5. Over one half of the land on and surrounding the sample small farms was woodland. While almost one-half of the land was open, only one-fourth was of cropland capability and less than 15 per cent was cropland in fields of size and shape that would allow the use of power machinery and equipment.

In actual practice the useable land on most of these enlarged farms would be less than this analysis indicates. The aerial photographs used were 10 to 20 years old and the criteria used to classify land on the maps are also dated. Some of the land shown on the photographs as open has reverted to brush or woodland, and some of the open land classified as suitable crop or pasture land has been reclassified in a lower use.

25 Farms were expanded on the maps by drawing a square of the appropriate size with the farmstead in the center. This procedure was necessary since the Soil Conservation Service did not have maps with the boundaries of sample farms and the neighboring units marked in.

26 It was assumed also that farmers could not purchase crop and pasture land on surrounding units without buying the wcodland. Farmers generally view their woodland as having little value, and perhaps of little or no value if it were separated from the open land in the unit, particularly in those cases where the woodland has no access to public roads except through the open land.

27 It was assumed that SCS land-use recommendations would be followed. Open land of landuse capability class I-IV was considered cropland, class VI as extensive pasture and class VII-VIII as suitable only for woodland. (SCS does not classify any land in West Virginia as V.)

Cropland fields not meeting minimum size standards were considered not suited to tillage with modern machinery and equipment and were counted as pasture land. Thus, regular-shaped fields of less than three acres and irregular fields of less than five acres were considered suitable only as pasture.

Since SCS describes class VI land as suitable for extensive pasture, woodland or wildlife, all such land was valued at one-third that of other land used as pasture.

Land stocked by trees of any size by 10 per cent or more was defined as woodland, and all woodland was assumed to remain so.

For each enlarger farm then, total cropland was equal to the sum of open land of capability class I-IV which lay in regular fields of three acres or more or irregular fields of five acres or more. Total pasture land was equal to one-third of the open class VI land plus the open land in class I-IV which did not qualify as cropland. 


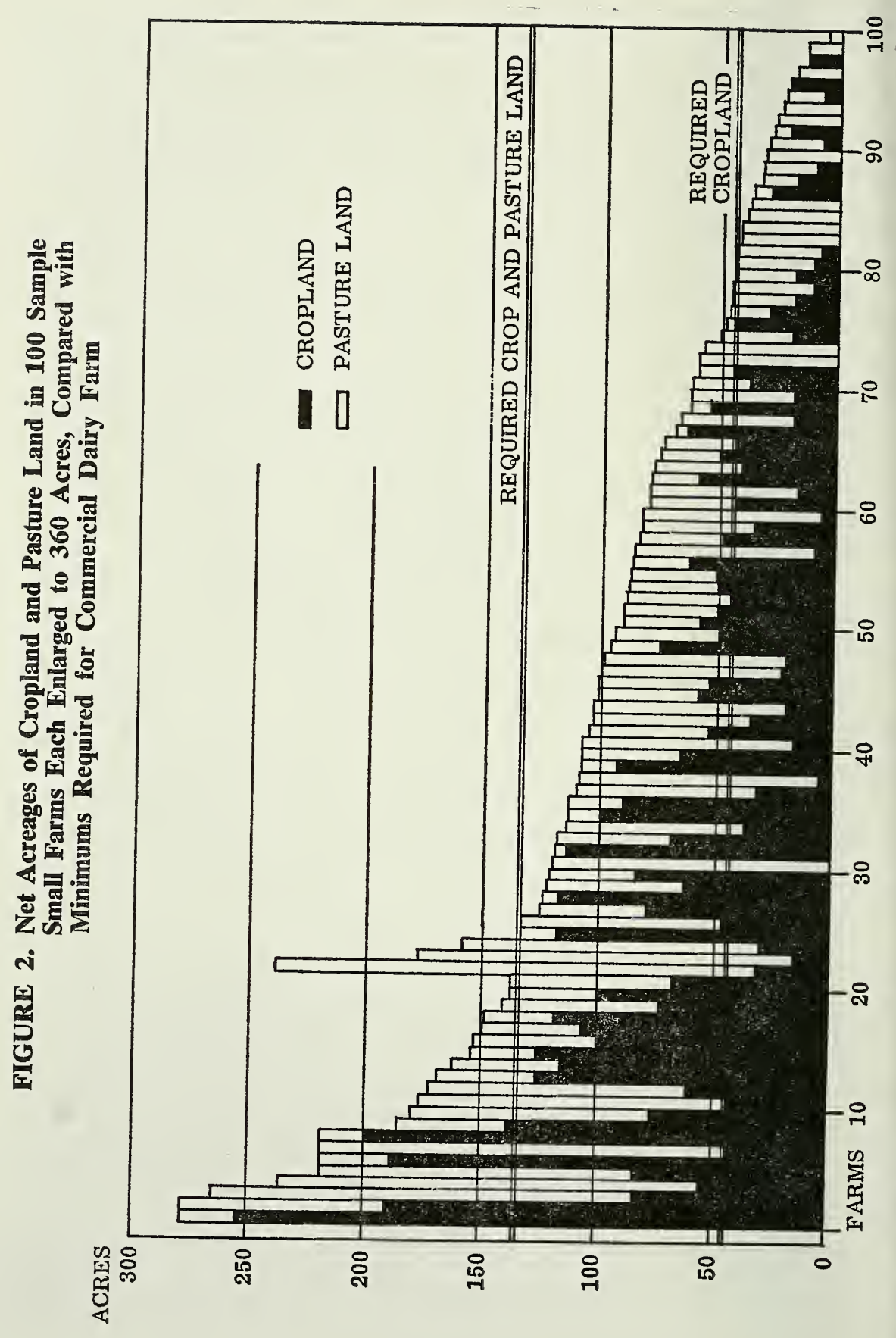




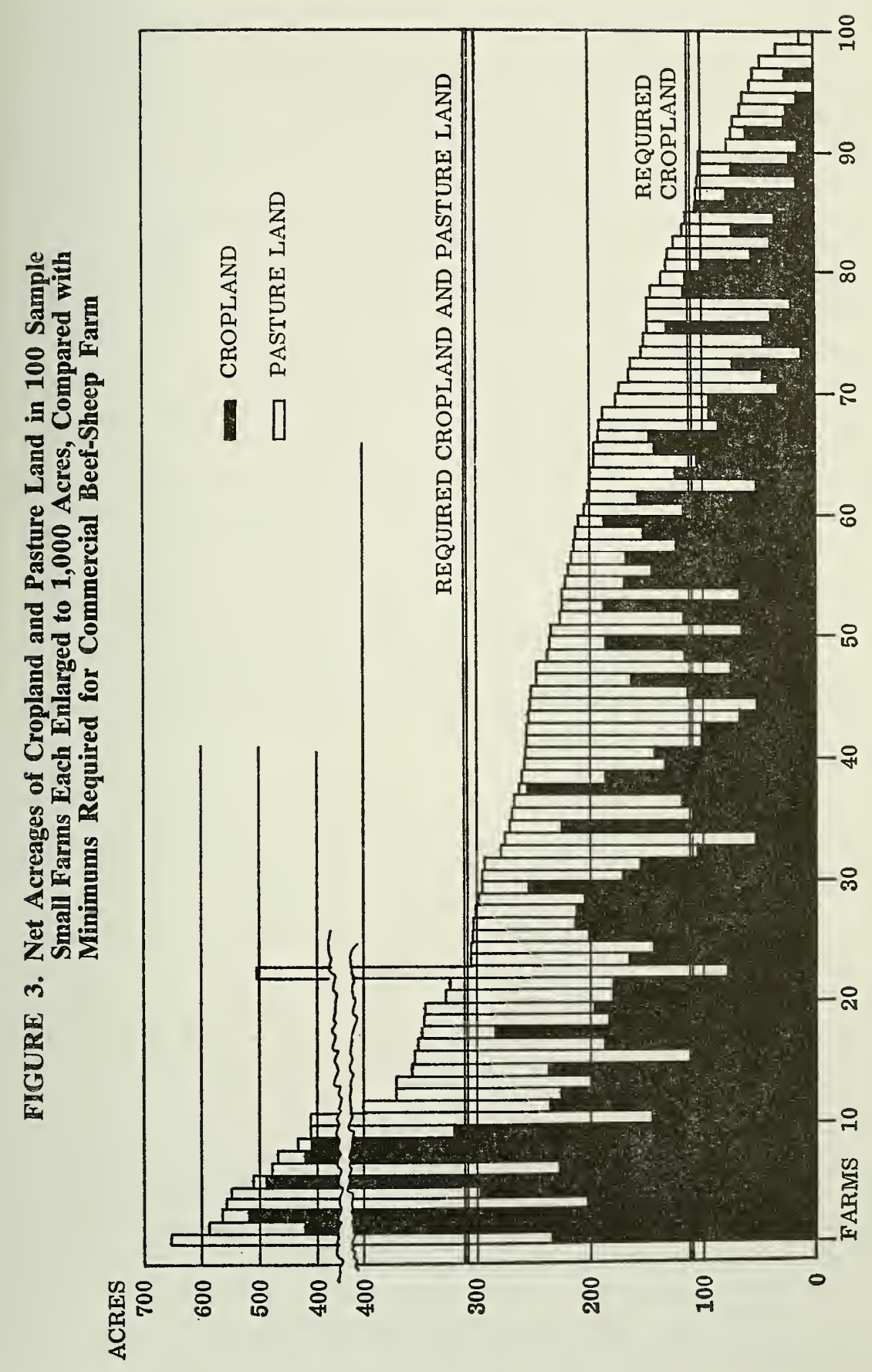


TABLE 5. Woodland, Cropland, Pasture Land, and Land-Use Capability Classes of Open Land in a Sample of 100 Small West Virginia Farms Enlarged to 360 and 1,000 Acres

\begin{tabular}{|c|c|c|c|c|c|c|}
\hline \multirow{3}{*}{ Item } & \multicolumn{3}{|c|}{ 360-Acre Units } & \multicolumn{3}{|c|}{ 1,000-Acre Units } \\
\hline & \multicolumn{2}{|c|}{ Acres } & \multirow{2}{*}{$\begin{array}{l}\text { Distri- } \\
\text { bution } \\
\text { per cent }\end{array}$} & \multicolumn{2}{|c|}{ Acres } & \multirow{2}{*}{$\begin{array}{l}\text { Distri- } \\
\text { bution } \\
\text { per cent }\end{array}$} \\
\hline & $\begin{array}{l}\text { (Aver- } \\
\text { age) }\end{array}$ & (Total) & & $\begin{array}{l}\text { (Aver- } \\
\text { age) }\end{array}$ & (Total) & \\
\hline Total acreage & 360 & 36,000 & 100.0 & 1,000 & 100,000 & 100.0 \\
\hline Woodland & 192 & 19,198 & 53.3 & 585 & 58,454 & 58.4 \\
\hline Open land & 168 & 16,802 & 46.7 & 415 & 41,546 & 41.6 \\
\hline $\begin{array}{l}\text { Capability } \\
\text { Class }\end{array}$ & & & & & & \\
\hline I & 7 & 652 & 1.8 & 14 & 1,414 & 1.4 \\
\hline II & 24 & 2,374 & 6.6 & 57 & 5,682 & 5.7 \\
\hline III & 27 & 2,677 & 7.4 & 66 & 6,560 & 6.6 \\
\hline IV & 36 & 3,650 & 10.1 & 85 & 8,515 & 8.5 \\
\hline$V^{a}$ & 一 & - & 一 & - & - & - \\
\hline VI & 26 & 2,623 & 7.3 & 70 & 6,967 & 7.0 \\
\hline VII & 47 & 4,725 & 13.1 & 122 & 12,246 & 12.2 \\
\hline VIII & 1 & 101 & .3 & 2 & 162 & .2 \\
\hline Cropland $^{\mathbf{b}}$ & 52 & 5,179 & 14.4 & 139 & 13,883 & 13.9 \\
\hline Pasture land ${ }^{c}$ & 50 & 5,048 & 14.0 & 108 & 10,810 & 10.8 \\
\hline
\end{tabular}

a The Soil Conservation Scrvice does not classify any land in West Virginia as $\mathrm{V}$.

b Open land of capability class I-IV which lay in regular fields of three or more acres or irregular fields of five acres or more.

c This figure represents acrcage equivalents of pasture land. It was obtained by adding the acreages of class I, II, III and IV land unsuitable for crops bccause of field size or shape and one-third of the acreage of class VI (extensive pasture) land.

In addition, in the process of expanding the sample farms, it was noted, from the maps and from general knowledge of the area, that some of the small farms that were successfully expanded were located next to residential areas which would restrict expansion.

Assuming that 19 out of 100 sample farms could be expanded, and that all small farms were expanded in like manner, less than 10 per cent might be successful because the better land is usually concentrated in certain areas. One successful expansion in those areas utilizes land that a neighboring small farm might expand into, thus precluding its successful expansion.

Appalachian land resources present a formidable obstacle to farm enlargement. Even if farmers were willing to consolidate land into 360-acre units to obtain 136 acres of land for a dairy operation or to consolidate land into 1,000-acre units to obtain 309 acres of land for a livestock operation, perhaps nine-tenths of the consolidations would not provide sufficient land. Also, 360-acre dairy farms and 1,000-acre livestock farms are already uneconomic because fields are widely scattered over a rough topography. 


\section{Human Resources}

Enlarging Appalachian farms by adding land requires also an addition of labor, capital, and management inputs. If land is not added in the enlargement process, more of the other inputs are required. In either case, these inputs must be increased by several times if a commercialsize farm is to be attained. The human resource on Appalachian farms in the role of labor and management is crucial to enlargement in whatever form it takes.

Data from 422 low-income farm operators on small West Virginia farms were evaluated to assess their suitability for commercial farming. ${ }^{28}$ These operators are believed to be typical of low-income Appalachian farmers generally. The labor requirement was assumed met if the operator were able-bodied, male, and under 65 years of age. The "managerial" requirements reflected factors that, if lacking, would effectively block the decision to enlarge farms. (The rationality of the decision was not at issue.) The requirements were: a recognition of family income as inadequate, a recognition of the possibility of earning more income by farming, and a willingness to mortgage real estate to obtain capital for farm enlargement. A farm operator had to meet the labor requirement and all of the "managerial" requirements to qualify.

The results are presented in Table 6. Only 2 per cent of the sample operators qualified by meeting the labor and "managerial" requirements. Over one-half failed to meet the labor requirement because they were over age, female, or disabled. Of those remaining, roughly one-third failed to qualify as each of the three "managerial" requirements was added. Since the set of requirements used here as criteria are necessary but certainly not sufficient conditions for successful enlargement and subsequent operation of an adequate-size commercial unit, these operators, for all practical purposes, have no future in commercial agriculture.

These results are not altogether surprising. The low proportion meeting the labor requirement is consistent with general knowledge about the area. The proportion of farm families with over age, female, or disabled heads is higher in the Appalachian area than in the rest of the country. The not unexpected finding here is that these families are concentrated in the low-income, small-farm category.

The almost total failure of sample operators to meet the "managerial" test is equally understandable. Two-thirds of the able-bodied operators under 65 years of age were 45 or older; three-fourths of them had only a grammar school education or less.

28 These 422 farm operators are from a 469 -family sample, described in the Appendix. Their incomes over a two-year period, 1957-58, averaged less than $\$ 4,000$ and they operated farms which grossed less than $\$ 5,000$ annually. 
TABLE 6. Proportions of Low-Income Operators on Small Farms Who for Specified Reasons Fail to Meet Labor and "Managerial" Requirements for Enlarging Farms, Sample of 469 West Virginia Families, 1959

\begin{tabular}{|c|c|c|c|}
\hline Factor & $\begin{array}{l}\text { Incom } \\
\$ 0-\$ 1,999\end{array}$ & $\begin{array}{l}\text { Class } \\
\$ 2,000-\$ 3,999\end{array}$ & Total \\
\hline $\begin{array}{l}\text { Labor requirement } \\
\text { 1. All low-income farm operators on small farms } \\
\text { 2. Operators } 65 \text { years or older } \\
\text { 3. Female operators under } 65 \text { years of age } \\
\text { 4. Male operators under } 65 \text { years of age with reported } \\
\text { physical or mental disabilities" } \\
\text { 5. Able-bodied male operators under } 65 \text { years of age } \\
\text { (line } 1 \text { minus the sum of lines } 2 \text {, 3, and 4) } \\
\text { "Managerial" requirement } \\
\text { (for operators recorded in line 5) } \\
\text { 6. Operators reporting incomes as adequate } \\
\text { 7. Operators reporting incomes as inadequate, but see } \\
\text { only "poor" possibility of earning adequate } \\
\text { income from farming ... } \\
\text { 8. Operators reporting income as inadequate, who see } \\
\text { a "fair" or "good" possibility of earning an } \\
\text { adequate income from farming but: } \\
\text { (a) who owned no real estate - } \\
\text { (b) who would not mortgage their real estate } \\
\text { for enlargement purposes } \\
\text { 9ble-bodied male operators under } 65 \text { years of age, } \\
\text { who reported income as inadequate, who believed } \\
\text { possibility of earning adequate income from } \\
\text { farming was "fair" or "good", who owned real } \\
\text { estate, and who would be willing to mortgage it } \\
\text { to enlarge their operations }\end{array}$ & $\begin{array}{r}53.6 \\
19.4 \\
2.3 \\
10.0 \\
21.9 \\
5.1 \\
6.2\end{array}$ & \begin{tabular}{|r} 
Cent of Operat \\
46.4 \\
12.9 \\
1.8 \\
9.5 \\
22.2
\end{tabular} & $\begin{array}{r}100.0 \\
32.3 \\
4.1 \\
19.5\end{array}$ \\
\hline
\end{tabular}

a Data were tabulated from 422 low-income families on small farms in the 469 -family sample. Income was averaged over a two-year period, 1957-58. Small farms were defined as those grossing less than $\$ 5,000$.

b The term disability as used here refers to a condition which in the view of the operator or a responsible member of the family limits the usefulness of the afflicted as a farm worker.

Perhaps of major importance is the fact that these individuals are part of a folk culture which, because of its orientation toward tradition and sentiment, tends to produce individuals who do not adapt readily to the entreprenuerial role. ${ }^{29}$ While the Appalachian area is undergoing rapid cultural change, remnants of the older culture still remain in the rural areas, hindering the development of the entreprenuerial mentality, without which subsistence farms cannot be converted to commercial units.

It is quite likely that this "cultural obstacle" is sufficiently embedded in the social matrix to keep the present generation of low-income farmers on small farms from enlarging their farms to commercial units even if other conditions were more propitious.

29 A study providing evidence that willingness to accept new ideas, an important entreprenuerial quality, is culturally determined is "Cultural Differences in the Acceptance of Recommended Practices," by Harold A. Pedersen, Rural Sociology, Vol. 16, No. 1, March 1951, pp. 36-49.

A discusslon of social systems and their implications is given in Charles P. Loomis, Social Systems, Essays on Their Persistence and Change, (New York: D. Van Nostrand Company, 1960); and Charles P. Loomis and J. Allan Bieglle, Rural Social Systeins, (New York: Prentice Hall, Inc., 1950). 


\section{Programs for Appalachian Farmers}

A comprehensive program for Appalachian farmers would provide sufficient employment opportunity for employable operators to achieve satisfactory incomes, means for unemployable operators to achieve satisfactory living levels, and a mechanism to prevent the perpetuation of the low-income, small-farm problem into succeeding generations.

A four-part program is suggested to meet these goals: (1) forest improvement projects; (2) labor retraining and outmigration; (3) increased welfare for the disabled and the retired; (4) an improved educational system for school-age youth. Costs and benefits, however crude and fragmentary, are estimated for forest improvement projects and for an improved educational system. Although estimates are based on West Virginia data and are made for the State, the broad implication for the region may be clear. It should be noted also that while most of the discussion on programs is devoted to forestry projects, an improved educational system is conceived to be the most important long-run solution to the low-income problem.

\section{Need for Income Programs}

Perhaps two-thirds of West Virginia's farmers are low-income small farmers, according to survey data. Their net annual income from all sources is less than $\$ 4,000$ and their farms gross less than $\$ 5,000$ per year (Table 7). With no future in commercial farming and no off-farm employment opportunity, they have no way to improve their incomes except through income programs.

Farmers who require no programs consist of those who operate adequate or near-adequate size farms and those already with adequate incomes, primarily from off-farm sources. Farmers operating nearadequate size farms might be expected to enlarge them, raising their incomes to the level enjoyed by operators of adequate units. Small farmers with adequate incomes are expected to hold their off-farm jobs.

The magnitude of the low-income, small-farm problem over time in West Virginia might be indicated by projecting the number of low-income farmers, by age grouping, in 1959 to the year 2000. These projections are recorded in Table 8. They rest on the assumption that no new low-income small-farm families will be formed over this period. How realistic this assumption is will depend upon the extent to which the nonfarm segment of the economy continues to employ those small farmers it presently employs, and its ability to absorb youth from small farms as they enter the labor force. 
TABLE 7. Estimated Number of Farmers on Adequate or Near-Adequate Size Commercial Farms, Small Farmers with Adequate and Low Incomes, West Virginia, 1959

\begin{tabular}{|c|c|c|c|}
\hline Item & \multicolumn{2}{|c|}{$\begin{array}{l}\text { West Virginia } \\
\text { Survey, } 1959\end{array}$} & $\begin{array}{c}\text { West } \\
\text { Virginia }\end{array}$ \\
\hline $\begin{array}{l}\text { Farmers operating adequate or near- } \\
\text { adequate size commercial farms }\end{array}$ & $\begin{array}{c}\text { (Number }{ }^{\mathrm{a}} \text { ) } \\
40.34\end{array}$ & (Per Cent) & (Number) \\
\hline Small farmers with adequate incomes ${ }^{c}$ & 82.50 & 23.64 & 13,357 \\
\hline Low-income small farmers & 226.17 & 64.80 & 36,612 \\
\hline Total farmers ${ }^{\mathrm{d}}$ & 349.00 & 100.00 & $56,500^{\circ}$ \\
\hline
\end{tabular}

a Decimals result from the fact that the data were drawn from a disproportionate sample. The sample is described in the Appendix.

b Farms were considered of adequate size if they grossed $\$ 10,000$ or more annually, nearly adequate if they grossed between $\$ 5,000$ and $\$ 9,999$. The sample overestimates the number of such farms since the Census of Agriculture for 1959, using the 1954 farm definition, reports that only 8.8 per cent or 4,972 farms grossed $\$ 5,000$ or more.

Incomes of $\$ 4,000$ or more were considered adequate.

d Columns may not add due to rounding.

- Census of Agriculture for 1959, using 1954 definition of a farm, adjusted for underreporting.

Whether these conditions will prevail is, of course, open to question. But several indications point in this direction. The major one may be a new awareness of the problem of unemployment in the Appalachian economy and attempts to solve that problem on all levels-local, state, and national. Another is that small farmers, in increasing numbers, are seeking off-farm employment. West Virginia survey data indicate that the younger farmers are either locating on the larger commercial-sized farms, or using the small farm primarily as a place of residence. These data also suggest and census data tend to confirm the notion that many of the older low-income small farmers did not choose farming as their major occupation, but were forced into farming when off-farm employment was no longer available to them. In any event, even under conditions of recession, the number of small farms is decreasing rapidly, and the percentage of small-farm operators working off-farm, either part time or full time, appears to be increasing steadily.

On the assumption that no new low-income, small-farm families are formed, the number of low-income, small-farm operators will decrease due to operator mortality. Starting with 36,000 low-income small farmers in 1960 , about 25,000 will remain in $1970 ; 16,000$ in $1980 ; 8,000$ in 1990 , and 4,000 in the year 2000 .

The number of jobs required to provide adequate incomes to employable operators over the 40-year period $1960-2000$ is estimated for 10 year intervals in Table 9 . These estimates were made by calculating the number of man-years required at a wage rate of $\$ 1.50$ per hour to raise average income of able-bodied operators under 65 from their present level of $\$ 2,500$ up to $\$ 4,000$. Adequate incomes for employable operators in 1960 would have required about 11,100 jobs. About 6,700 jobs would 
TABLE 8. Projection from 1960 to 2000 of Numbers of West Virginia Family Heads Who Were Low-Income, Small-Farm Operators in 1958, by Age

\begin{tabular}{|c|c|c|c|c|c|c|c|}
\hline & \multirow{2}{*}{ Age } & \multirow{2}{*}{\begin{tabular}{|c|}
$\begin{array}{c}\text { West Virginia } \\
\text { Survey, 1959a }\end{array}$ \\
$\$ 0-\$ 3,999$ \\
\end{tabular}} & \multicolumn{5}{|c|}{ West Virginia $^{\mathbf{b}}$} \\
\hline & & & $1960^{\circ}$ & 1970 & 1980 & 1990 & 2000 \\
\hline Under 2 & 25 & $\begin{array}{c}\text { (Per Cent) } \\
1.3\end{array}$ & 500 & - & - & - & - \\
\hline $25-34$ & -1- & 7.2 & 2,600 & 500 & 一 & - & - \\
\hline $35-44$ & & 14.4 & 5,300 & 2,500 & 400 & - & $\rightarrow$ \\
\hline $45-54$ & - & 21.8 & 8,000 & 4,900 & 2,400 & 400 & - \\
\hline $55-64$ & . & 22.7 & 8,300 & 7,100 & 4,400 & 2,100 & 400 \\
\hline 65 and & over & 32.3 & 11,800 & 10,400 & 8,600 & 6,000 & 3,200 \\
\hline Total $^{\mathbf{d}}$ & $\ldots$ & 100.0 & $36,500^{\circ}$ & 25,400 & 15,800 & 8,500 & 3,600 \\
\hline
\end{tabular}

a Percentages are based on the low-income, small-farm component of the sample.

b The number of farm operators in each category for 1960 is based on the assumption that the sample was representative. Estimates for succeeding years are 1960 data adjusted by expected mortality rates. Since the median age exceeds the mean age for all except the open-ended age groups, the average mortality rate for each group was assumed to be that of individuals six years older than the lower age in that group's age range. For the group less than 25 years, the mortality rate was assumed to be that of 22-year-olds and for the group 65 years and over, the rate was assumed to be that of 70 -year-olds. In the 65 and over group for 1960 , 70 per cent were assumed to be $65-74$ and 30 per cent 75-84. Actuarial data are from the Federal Security Agency publication, State and Regional Life Tables, 1939-41, (Public Health Service, National Office of Vital Statistics), (Washington: U. S. Government Printing Office, 1948) pp. 254-255. data.

No adjustment was made for the difference in years in estimating 1960 estimates from 1959

d Totals do not always add due to rounding.

- This figure was obtained by multiplying. the percentage of low-income small farmers in the 1959 West Virginia survey by the number of farms in 1959 according to the 1959 Census, adjusted for underreporting, and using the 1954 Census definition.

be required in $1970,3,200$ in 1980 , and 1,100 in $1990 .^{30}$ Since there are four times as many Appalachian as West Virginia farmers, ${ }^{31}$ employment needs for the Appalachian area might be roughly four times these estimates.

The number of unemployable farm operators in West Virginia is estimated to have been about 14,200 in 1960 . It is estimated that 12,000 will be unemployable in $1970,9,400$ in 1980 , and 6,200 in 1990. These operators will be unemployable because of old age or disability. The Appalachian region, again, may have four times this number. While the West Virginia survey data do not permit a calculation of average income for disabled operators, income for operators over 65 was estimated to average $\$ 1,600$. If a $\$ 2,100$ income provides a satisfactory level of living for retired couples, ${ }^{32}$ incomes for this group are now inadequate and, should the same relation hold in the future, this group will be in need of considerable help.

30 It is understood that in using $\$ 4,000$ as an adequate income for employable operators to determine employment needs for 1960 and then extrepolating these needs to the year 2000 does not imply that incomes of this group, if employed, need remain around $\$ 4,000$ over the 40 -year period. Over time the returns to labor will increase and incomes to this group will thus tend to rise above this level.

31 Appendix Table 1.

32 Appendix Table 8. 
1. Estimated average income, low-income small farmers, West Virginia ${ }^{2}$

a. All farmers

b. Able-bodied farmers under 65 years

$\$ 2,200$

c. Farmers 65 years and over

2. Family income defined as adequate

a. Able-bodied farmers under 65 years

$\$ 4,000$

b. Disabled farmers under 65 years

c. Farmers 65 years and over

3. Difference between average income and adequate income

a. Able-bodied farmers under 65 years

(line $2 \mathrm{a}$ minus line $1 \mathrm{~b}$ )

b. Disabled farmers under 65 years

c. Farmers 65 years and over

4. Estimation of labor pool, able-bodied farmers under 65 years

a. Man-years required for farmer with average income to earn difference between his present income and $\$ 4,000^{\mathrm{d}}$

b. Estimated man-years of employment required to increase average income to $\$ 4,000^{\circ}$

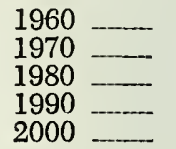

5. Estimation of potential welfare pool

a. Farmers 65 years and over ${ }^{2}$

b. Disabled farmers under 65 years $^{\mathrm{g}}$

a Average incomes are based on 1958 data from the West Virginia survey; incomes for all low-income small farmers in that survey averaged $\$ 2,170$, incomes for farmers under 65 averaged $\$ 2,442$, and for farmers 65 and over, $\$ 1,598$. Average income for able-bodied farmers was rounded at $\$ 2,500$, instead of $\$ 2,400$ since the sample group of farmers under 65 included a number of disabled individuals whose incomes were probably lower than the average for the group.

b Not estimated due to lack of data.

c Calculated average required for low-income elderly families to meet measure of income adequacy specified in Appendix Table 11 is $\$ 2,708$. Average size of family was 3.2 . When economic conditions improve, many children living with their elderly parents during the recession will move back to their jobs reducing the average size of elderly families. It is assumed that elderly families would then average about two members, for which $\$ 2,100$ is adequate according to Appendix Table 8.

d At $\$ 1.50$ per hour, 125 eight-hour days would be required to earn $\$ 1,500$. A man-year is defined as 250 days.

Number of farmers under 65 (from data in Table 8 before rounding), adjusted downward by 10 per cent of farmers assumed to be disabled, times .5 equals estimated man-years. Estimates are rounded to hundreds.

1 From the data in Table 8 before rounding. Estimates are rounded to hundreds.

s Assumed to be 10 per cent of farmers under 65 years. About 29 per cent of the farmers under 65 in the West Virginia survey reported a disability that interfered with their usefulness as farm workers, but since two-thirds of these disabled individuals reported an interest in local employment programs, it was assumed that these disabilities were not sufficient to preclude off-farm employment. Estimates are rounded to hundreds.

h Less than 100 . 
The magnitude of the problem, roughly outlined above, indicates that federal aid is required if Appalachian farmers' incomes and levels of living are to improve. The time dimension of the problem may be as high as 40 years. Projecting West Virginia data, Appalachian farmers may need in 1965 more than 30,000 jobs not now available; in 1970 about 25,000; in 1980 about 10,000; in 1990 about 5,000; and in the year 2000, just 1,000 jobs. The unemployable, due to over age and disability, over those same points in time may amount to $50,000,45,000,35,000,25,000$, and 15,000 .

The geographic and vocational immobility of many Appalachian small farmers requires some local programs that can utilize unskilled labor. While three-fourths of the low-income West Virginia farm operators surveyed in 1959 indicated an interest in federal programs that would generate local employment utilizing the skills they had, only one-third were interested in programs of retraining or in moving them out of the area (Table 10). This is not surprising because these farmers are older and have little formal education. One-third of those under 65 were 55-64, another one-third were 45-54, and three-fourths had only a grammar school education or less.

\section{Programs}

\section{A. Forest Improvement Projects}

In addition to a number of other benefits, forestry projects appear to have potential for simultaneously improving the lot of the present generation of Appalachian farmers, and preventing a new generation of low-income small farmers from getting started.

To illustrate what might be expected from a program of forest improvement, a 1-million acre forestry project was hypothesized for West Virginia, and some costs and benefits were estimated, based on the limited data available. These estimates were made on the assumption that the project area reflected average conditions for those areas in the State where small farms predominate, and that forest improvement would proceed under the management of professional foresters. All opencountry land, except that suited to commercial farms and desired for rural residences and commercial enterprises, would be planted to forest, and all present woodland would undergo an improvement program. Land in the forestry project-the residual when land for commercial farms, rural residences, and commercial enterprises is substracted-was assumed to be I million acres. ${ }^{33}$

33 A project of this size would encompass four to six counties. An actual project might be larger or smaller than this, depending upon economies of scale and other factors. 
TABLE 10. Some Characteristics of Low-Income, Small-Farm Operators, and Operators' Responses to Questions Concerning Federal Programs to Improve Incomes, West Virginia Survey, 1959

Item

Per Cent

Characteristics of farm operators

Age distribution

less than 25 years

25-34

$35-44$

$45-54$

$55-64$

2.2

10.6

21.4

31.9

Formal education

$0-8$ years 33.9

9-12 years

13 years or more

Questions ("yes" and "maybe" answers are recorded together)

Would you be interested in a federal program

a. to make more jobs available to you in the area?

b. of night or day school so you could learn a trade?

76.9

54.4

c. to establish an employment agency service which would supply you with information on job openings in other areas, the wages paid, etc.?

d. to loan money to families who want to move to where jobs are and want to buy a house or small farm there?

e. to loan money to families who want to move to where jobs are?--

a Total number of farmers in this sub-sample was 153.2. This number is not whole because the sample was disproportionate. The 1959 sample is described in the Appendix.

b Applies only to operators less than 55 years of age.

\section{(1) BENEFITS}

1. Adequate incomes to all employable operators through off-farm employment. On the basis of available data, a major forestry project might provide employment for all surplus farm-operator labor in the project area from its initiation to the year 2000. Figure 4 shows the relation between project employment opportunities and surplus farmoperator labor in the project area. The smooth curve labeled "area farm-operator labor pool" represents the project area's share of surplus farm-operator labor on West Virginia farms and the shaded area represents the employment afforded by the forestry project. Data for Figure 4 are calculated in Table 11. From 1965 to the year 2000, when only a few employable operators remain, the demand for labor at least equals the supply in most of the years. Postponing some of the work in periods of excess demand to years of excess supply would fit demand to supply over the entire period.

2. Local employment suited to the tastes and skills of farm operators. Appalachian farmers would rather find employment near home than move their families to a new area and subject them to the stresses of 
FIGURE 4. Employment Afforded by 1-Million Acre Forestry Project Relative to Surplus Labor on Farms in the Project Area, West Virginia (Drawn from data in Table 11)

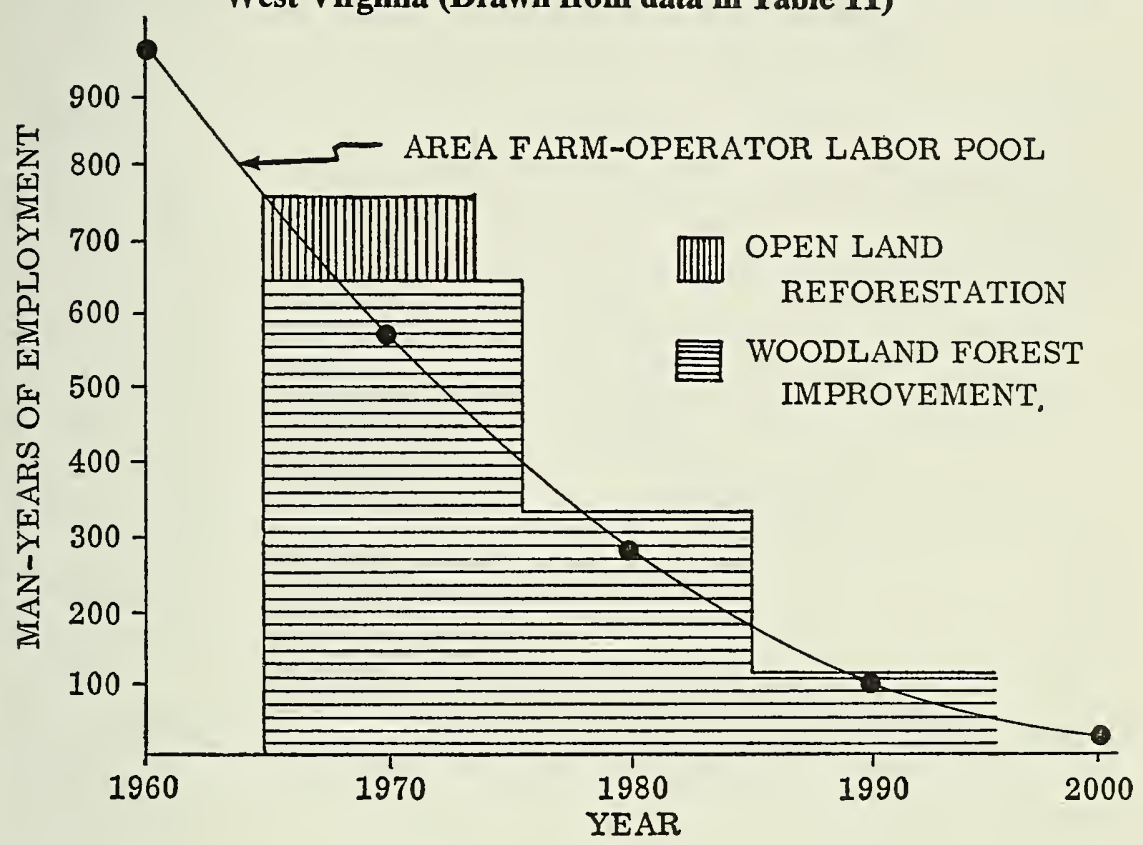

inter-cultural conflict. Of the jobs sometimes available to them, these farmers might find work in the woods more appealing.

3. Increased benefits to employable operators upon retirement. Over the 35-year period 1965-2000, perhaps 45 per cent of the operators, on the average, will be employable. ${ }^{34}$ Some of these individuals are not insured under the social security program, or are insured at minimum benefit levels. ${ }^{35}$ Employment in a forestry project would insure those not now insured and would increase the benefits of those now insured at the lower benefit levels.

4. Cash-in-hand for employable operators who wish to leave the area for employment elsewhere. Owners of average West Virginia small farms, if unencumbered, would receive about $\$ 2,900$ from the sale of land to the forestry project authority. ${ }^{36}$ This is enough money to finance a move out of the area. Those who wish to move and purchase a house or small farm in a new locality could borrow money

34 Calculated from Table 8, assuming that 10 per cent of the farmers under 65 years are disabled. See footnote $\mathrm{g}$, Table 9 .

35 In the 1959 West Virginia survey, 40 per cent of the farm operators 65 and over reported receiving no social security benefits and 18 per cent reported benefits under $\$ 500$.

36 Column 4, Table 12. 
TABLE 11. Estimation of Employment Afforded by Hypothesized 1-Million Acre Forestry Project Relative to Surplus FarmOperator Labor on Farms in Project Area, West Virginia

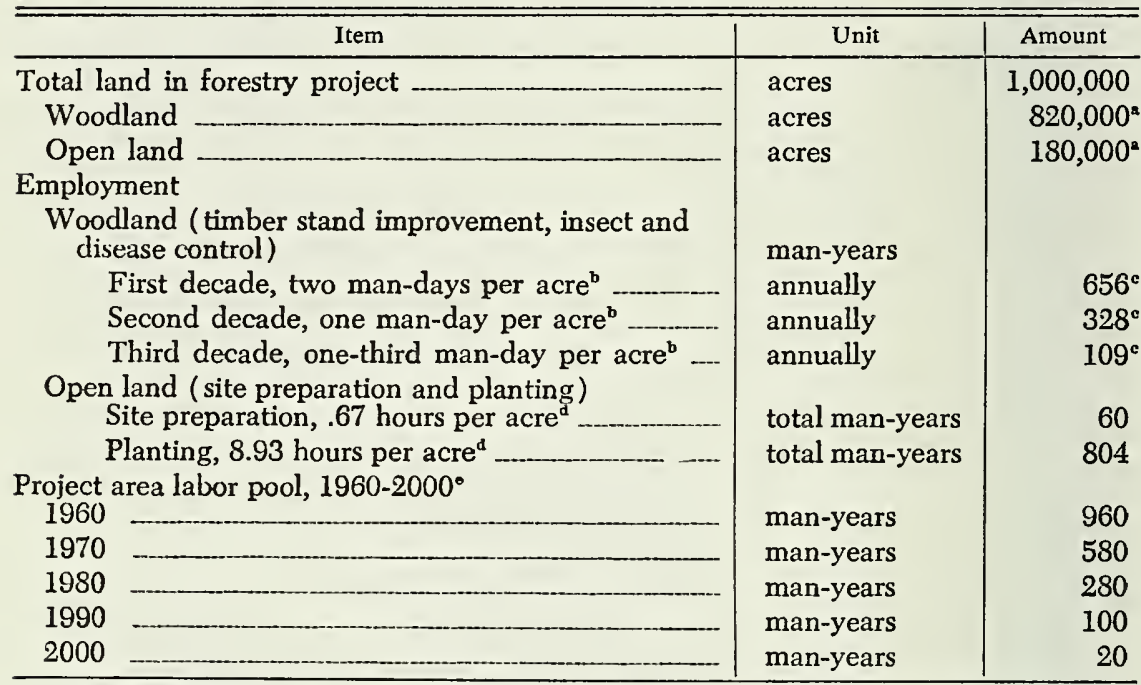

The proportions of woodland and open land were assumed to be typical for the 11.6 million acres of land deemed suitable for reforestation in West Virginia. See Table 15.

b United States Congress, Senate, The Timber Resources of West Virginia and a Report on the National Forests of West Virginia: Reports prepared by the Forest Service, U. S. Department of Agriculture, Senate Document No. 33, 87th Congress, First Session, presented by Mr. Byrd of West Virginia (Washington: Government Printing Office, 1961) p. 11.

c New employment would amount to a little less than these figures, perhaps 10 man-years less, since a small amount of this work (estimated from ibid.) is currently being carried on.

d These estimates are reported for hand-planting pine on open fields of less than 12 acres, in Input Data: Study of Farm Forestry Opportunities in the Solthern Piednont of Virginia, (mimeograph), Charlottesville Research Center, Southeastern Forest Experiment Station, Division of Forest Economics, Asheville, North Carolina, August 3, 1961, p. 3. The spacing was $7 \mathrm{ft}$. $\times 9 \mathrm{ft}$., allowing about 700 seedlings per acre.

e Dividing the labor pool for West Virginia farm operators (Table 9, item 4b), before rounding, by 11.6 yields the labor pool in an average 1 -million-acre area. Quotients are rounded to tens. Land suitable for forestry was estimated to be 11.6 million acres (Table 15).

to supplement these funds. The risk for those who wish to move to areas where employment is more plentiful might be reduced by allowing them life estate rights to, perhaps, three acres of land which would include their farmsteads. Over 90 per cent of the employable operators in the 1959 West Virginia survey reported owning their farms.

5. Retirement funds for operators now over age 65 and disabled operators now under 65 years. In a preceding section the average income of retired operators was estimated to be short of adequate by about $\$ 500$. Incomes of disabled operators are probably inadequate also.

Most of these individuals own their own farms, and could raise needed funds by selling their land. In the 1959 West Virginia survey, 92 per cent of the low-income, small-farm operators 65 and over owned 
their farms. Forty-four per cent of the operators reporting a disability were in the 55-64 age group. Because the degree of disability tends to increase with age, it is likely that this age group contains the bulk of the individuals whose disabilities are serious enough to prevent them from obtaining off-farm employment. In the survey, 92 per cent of the operators 55 to 64 years of age also owned their farms.

To further the objective of providing retirement funds to these groups, retired and disabled individuals might be offered, in lieu of a cash settlement for their land, a retirement payments plan to run for the remainder of their lives. Monthly payments to any individual might be based on the value of the land in his farm, his life expectancy, and the interest that would accrue over that period on the unpaid balance. These individuals might be given a life estate of, perhaps, three acres of land, including the farmstead, thus allowing them to continue some part-time farming and to live out their years in their own communities.

Estimates of average payments in retirement are given in Table 12. Assuming that disabled operators 55-64 and operators 65 and over own average-size small farms, average annual payments to the former would amount to about $\$ 235$ and about $\$ 300$ to the latter, plus interest. If disabled individuals chose to have payments begin from the time of sale rather than upon their reaching 65 years of age, payments would, of course, be smaller. To the extent that disabilities adversely affect longevity, payments would be larger than recorded. These data indicate that under this kind of program about 90 per cent of the operators 65 years and over and perhaps half of the disabled operators under 65 in the forestry project area could benefit by way of a modest guaranteed income for life. ${ }^{37}$ In the case of retirement-age operators, average payments go almost half-way toward closing the gap between their average income and an adequate income. Although disabled operators under 55 years would not benefit in terms of total retirement needs as much as those 55 to 64 , because their remaining life span is longer, they would clearly benefit to some extent. It is likely also that in this group a smaller proportion own farms and of these a number will be encumbered. In the West Virginia survey, 70 per cent of the disabled operators under 65 owned farms.

6. Permanent diversion of resources from inefficient agriculture. The purchase and subsequent inclusion of land not suited to agriculture into a forestry project would provide a permanent solution to the lowincome, small-farm problem per se in the project area. All open land, except for residential sites (to average about three acres per site) and commercial farms, would be reforested. However, since small farmers

37 Farms were assumed free of encumbrances. 
TABLE 12. Estimated Payments in Retirement to Low-Income, SmallFarm Operators 65 and Over and to Disabled Operators Under 65 from Sale of Faims, Hypothesized Forestry Project, West Virginia

\begin{tabular}{l|c|c|c|c|c}
\hline \multicolumn{1}{c}{$\begin{array}{c}\text { Age of } \\
\text { operator }\end{array}$} & $\begin{array}{c}\text { Proportion } \\
\text { who own } \\
\text { farms }\end{array}$ & $\begin{array}{c}\text { Average } \\
\text { number } \\
\text { of years } \\
\text { of life } \\
\text { remaining }\end{array}$ & $\begin{array}{c}\text { Average } \\
\text { value of } \\
\text { farm land }\end{array}$ & $\begin{array}{c}\text { Monthly } \\
\text { payment }\end{array}$ & $\begin{array}{c}\text { Annual } \\
\text { payment }^{\mathbf{d}}\end{array}$ \\
\hline $55-64$ & .92 & $12.43^{\mathrm{a}}$ & $\$ 2,910$ & $\$ 20^{\mathrm{t}}$ & $\$ 234^{\mathrm{t}}$ \\
65 and over - & .92 & 9.57 & 2,910 & 25 & 304 \\
\hline
\end{tabular}

a West Virginia survey, 1959.

b Federal Security Agency, Public Health Service, National Office of Vital Statistics, State and Regional Life Tables, $1939-41$, p. 255.

c Average size of farm was assumed to be 93 acres, equal to the average for all small farms in West Virginia according to the Census of Agriculture, 1954. Proportions of cropland, pasture and woodland were assumed to be equal to that for all West Virginia farms. Land price data are from U. S. Department of Agriculture, Economic Research Service, Farm Real Estate Market Developments, CD-61, June 1962, p. 30, and CD-63, April 1963, p. 16.

d Average value of farm land divided by average number of years of life remaining. These estimates do not include interest payments.

At age 65. To the extent that disabilities affect longevity adversely, this figure is an overestimate.

Payments were calculated on the assumption that payments would not begin until age 65 .

would retain a sufficient amount of open land to produce food for the household (about three acres), the major source of farm income for most families would remain.

7. Cash-in-hand to nonfarm landowners. Like owners of small farms, holders of other land in the project area would benefit by selling to the forestry agency. Much of this land offers little prospect of income to present owners because it is abandoned farm land or cutover woodland. Land sales would particularly benefit those owners now unemployed, employed part-time, or retired due to old age or disability, because sales would provide funds to supplement present incomes. Rural residents could sell land without disrupting their ties to the community because they could retain three acres as a residential site. Residents in isolated areas who wish to sell their entire holdings with a view toward re-establishing themselves nearer town on better roads could do so. This would allow families to avail themselves of opportunities that do not exist on the back roads.

8. Limited employment opportunity for nonfarmers during the forest development period 1965-2000. The improvement program conducted on the woodland acres would result in a gradual increase in the annual allowable cut of sawtimber from about 60 board feet to about 110 board feet per acre over a 40 -year period, ${ }^{38}$ providing a small amount of new employment. The reforestation program on the open land

38 United States Congress, Senate, The Timber Resources of West Virginia and a Report on the National Forests of West Virginia: Reports prepared by the Forest Service, U. S. Department of Agriculture, Senate Document No. 33, 87th Congress, First Session, presented by Mr. Byrd of West Virginia (Washington: Government Printing Office, 1962) p. 10. 
would also provide some periodic employment. It is assumed that suitable varieties of softwood would be planted on open land to serve as protective cover for hardwoods which would seed naturally. The softwood stands would require periodic care, mainly thinning, which might be carriei sut 6 to 10 years after planting and again 20 years later (thinned trees from the first operation might be sold as Christmas trees, and from the second operation, for pulpwood).

9. Benefits to the local economy. The local economy would benefit from the sale of land to the forestry authority and from the subsequent employment that the project would provide. Both activities would bring new money into the area, creating new demand, and through the multiplier effect, tend to improve incomes generally. The effect would be particularly significant during the first 10 years of the program when land payments are made and forest employment is highest.

The local economy would benefit in the longer run because a restored forest could support many more workers than it does at present. Table 13 compares present and potential employment after an improvement program of 40 or more years. While the 820,000 acres of woodland in the proposed project area now support about 450 jobs, they would become capable of supporting from 4,600 to 13,300 jobs,

TABLE 13. Potential Employment in Lumber, Remanufacturing, Pulp and Paper Industries, Hypothetical 1-Million Acre Forestry Project After Improvement Program of 40-Plus Years, West Virginia ${ }^{a}$

\begin{tabular}{|c|c|c|}
\hline \multirow{2}{*}{ Processing } & \multicolumn{2}{|c|}{ Man-years of employment } \\
\hline & Present ${ }^{b}$ & Potentialc \\
\hline Lumber and remanufacturing: & \multirow{3}{*}{430} & \multirow[b]{2}{*}{3,230} \\
\hline $\begin{array}{l}\text { Logging, sawmilling, present low } \\
\text { level of remanufacturing }\end{array}$ & & \\
\hline $\begin{array}{l}\text { Logging, sawmilling, with medium } \\
\text { level of remanufacturing }\end{array}$ & & 4,530 \\
\hline $\begin{array}{l}\text { Logging, sawmilling, with high } \\
\text { level of remanufacturing }\end{array}$ & $\cdots$ & 7,760 \\
\hline $\begin{array}{l}\text { Paper and pulp: } \\
\text { Pulpwood production }\end{array}$ & 20 & 1,420 \\
\hline Pulpwood and pulp & $\ldots$ & 2,950 \\
\hline Pulpwood, pulp and paper & $\ldots$ & 5,530 \\
\hline
\end{tabular}

a This table is adapted from Table 7 and Table 8, The Timber Resources of West Virginia and a Report on the National Forests of West Virginia: Reports prepared by the Forest Service, U. S. Department of Agriculture, Senate Document No. 33, 87th Congress, First Session, presented by $\mathrm{Mr}$. Byrd of West Virginia (Washington: Government Printing Office, 1961).

b Project area was assumed to have a proportionate share of the total for the State.

c Based on anticipated production and cut on 820,000 acres of woodland. It is assumed that the annual growth and cut per acre would average 300 board feet of sawtimber plus 30 cubic feet of material of less than sawtimber size. Present annual growth and cut of sawtimber per acre is 90 board feet and 40 board feet respectively. The cut of wood materials of less than sawtimber size per acre is relatively minor. 
depending upon the amount of local processing of forest products. A tenfold increase in employment would result from increased forest output. A nearly thirtyfold increase is possible if the improved quality of sawtimber is fully utilized in the remanufacture of higher quality products, and if the increased production of other wood material is processed locally. After a period of time in excess of 40-plus years, the 180,000 acres of open land would come into production, affording still more employment.

10. Benefits to local government. By providing a ready market for land, the forestry authority would accelerate the exodus of population from isolated valleys, resulting in more efficient use of public resources. For example, as isolated farms are abandoned, the back roads serving them could be abandoned.

(2) costs

The major outlays of funds for a 1-million acre forestry project are estimated in Table 14. Outlay for land purchases would be $\$ 29$ million and would be made early in the first decade of the project. Labor expenditures would occur over a 30 -year period. On woodland acres, annual outlay for labor for the first decade would be about $\$ 2$ million; in the second decade, about \$1 million; and in the third decade, about $\$ 300,000 .{ }^{39}$ Outlay for labor in reforesting open land would be $\$ 2.5$ million; machine costs, a quarter of a million dollars; and seedling stock, about $\$ 1.9$ million. Open land reforestation would presumably occur in the first decade of the project, as shown in Figure 4, although it could be done at any time. Other expenses-land taxes, fire protection, road maintenance, and administration-were estimated at $\$ 6$ million per decade. Total outlay over the 30-year period might amount to $\$ 85$ million, with the bulk of this expenditure- $\$ 60$ million-being paid out over the first decade.

In the long run the net cost of the project to the federal government would be less than this. To illustrate, consider probable costs and returns for an average woodland acre. ${ }^{40}$ Assume that 45 years is required to bring the level of stocking and productivity up to the desired level6,000 board feet of standing timber with an annual growth and cut of 300 board feet of sawtimber plus 30 cubic feet of wood material of less than sawtimber size. ${ }^{41}$ Assume further an interest rate of 3 per cent on

39 Since wage rates are expected to rise through time, labor costs for the second and third decades would be higher.

40 Land currently in trees.

41 United States Congress, Senate, op. cit., pp. 8, 11. It is estimated that at least 40 years would be required to attain this level of stocking and growth, but that once attained, the entire annual growth could be harvested. 


\section{TABLE 14. Estimated Outlays by Decades for Hypothesized 1-Million Acre Forestry Project, West Virginia}

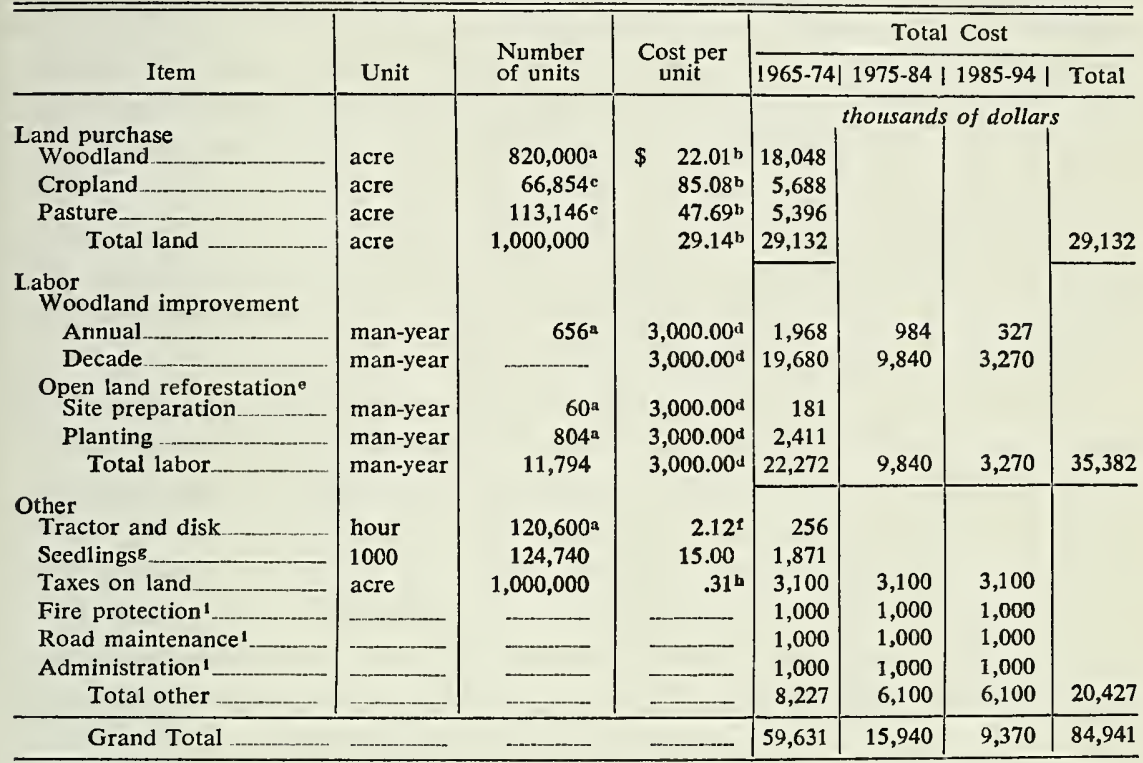

a Table 11 .

b U. S. Department of Agriculture, Economic Research Service, Farm Real Estate Market Developments, CD-61, June 1962, p. 30, and CD-63, April 1963, p. 16. The value of "other land" which includes woodland pastured, woodland not pastured, wasteland, and land in farmsteads, roads, etc., was $\$ 21.00$ per acre for West Virginia in 1960 ; the value of cropland was $\$ 81.17$ per acre and the value of pasture was $\$ 45.50$ per acre. These values were adjusted upward by 4.82 per cent, the increase in value of farm real estate in West Virginia from 1960 to November, 1962. Pasture includes cropland used only for pasture, and other pasture (excluding cropland and woodland). These estimates do not include the value of buildings.

c The proportions of cropland and pasture were assumed to be the same as those reported for all open land by the West Virginia Conservation Needs Committee, State Soil Conservation Committee, West Virginia Soil and Water Conservation Needs Inventory, 1961, p. 7.

$d$ The hourly rate for labor was assumed to be $\$ 1.50$. A man-year is 250 eight-hour days.

- No estimates of costs of periodic thinning were made since these operations would pay for themselves through the sale of thinned trees.

Input Data: Study of Farm Forestry Opportunities in the Southern Piedmont of Virginia, (mimeograph), Charlottesvilie Research Center, Southeastern Forest Experiment Station, Divislon of Forest Economics, Asheville, North Carolina, August 3, 1961, p. 3.

g Norway Spruce, Red, White, or Scotch Pine or some other variety of softwood suitable to the site would be planted on open land.

b U. S. Department of Agriculture, Economic Research Service, Farm Real Estate Taxes, RET-2, October 1962, p. 7. Taxes levied per acre of farm real estate for West Virginia in 1961 were 31 cents.

1 Estimated in part on basis of recent expenditures for these items on national forest lands in West Virginia.

the investment; compounded annually, and constant prices, say $\$ 12$ per thousand board feet of sawtimber on the stump of the size, variety, and density now found on woodland acres, and $\$ 2$ per cord for material of less than sawtimber size.

Total expenditures on one acre ( $\$ 44.31$ ) plus interest to the end of the 45-year period would amount to $\$ 258.77$. Annual receipts from the sale of sawtimber plus interest over this same period would equal 
$\$ 89.72,{ }^{42}$ leaving a balance of $\$ 169.05$. Three per cent of $\$ 169.05$ is $\$ 5.07$, the annual return required after completion of the improvement program if the return on investment is to equal 3 per cent. Three hundred board feet of sawtimber at $\$ 16.61$ per thousand and 30 cubic feet of material of less than sawtimber size at $\$ 2.00$ per cord (128 cubic feet) yields an annual return of $\$ 5.07$. To realize a return of 3 per cent on the investment then, the stumpage price of sawtimber need rise only $\$ 4.61$, according to these calculations. Since the improvement program would increase the density of the more desirable species and the overall quality and density of the stand, a quality premium of $\$ 4.61$ does not seem unreasonable. ${ }^{43}$

These simple calculations indicate a return on investment on woodland acres of about 3 per cent. Since woodland investment is threefourths of the total investment, it may be reasonable to conclude that under ordinary conditions, a forestry project might either pay for itself or come reasonably close to doing so.

It must be emphasized that these conclusions are very tentative. Estimates of costs and benefits are based on extremely crude and fragmentary data. Further, they are based on the assumption that long-run demand for forest products will be such that prices will be maintained at present levels. While there is some basis for assuming an increasing demand for wood products, in the light of advances being made in the chemical industries, and the increased production that would result from a general forestry program, the assumption needs some substantiation before a forestry solution can be considered feasible.

This first approximation of costs and benefits of forest improvement programs, therefore, suggests some further areas of research. More precise demand-supply estimates for forest products for the long run are needed as a basis for more precise cost-benefits estimates. More generally, there is need for overall cost-benefits estimates of Appalachian forests in a multiple-use context.

(3) PROGRAM ACCEPTANCE

A public program, even if economically feasible, is not acceptable unless its means and ends coincide in a general way with the desires of the people affected. While it may be agreed that benefits generated by the program are desirable and that program costs are not prohibitive,

42 Receipts were estimated from United States Congress, Senate, ibid., figure 5, p. 10, showing annual allowable sawtimber cut per acre over the first 40 years of an improvement program. Allowable cut is expected to increase from 60 board feet in the first year to 110 board feet in the fortieth year.

43 Stumpage prices vary considerably by species and within species. For example, in West Virginia in the second quarter of 1963 , hickory (sawlogs) sold on the stump averaged $\$ 5.75$ per thousand board feet, red maple averaged $\$ 15.20$, and cherry averaged $\$ 28.90$. Over this same period, the range of prices paid per thousand board feet for hickory was $\$ 3-\$ 10$, for red maple, $\$ 8-\$ 42$, and for cherry, $\$ 12-\$ 40$. Average price for all sawlog stumpage sold was $\$ 13.60$. U. S. Department of Agriculture, Federal-State Crop Reporting Service, Statistical Reporting Service, and West Virginia Department of Agriculture, West Virginia Forest Products Market Information, Vol. 4, No. 2, September 1963. 
a program involving extensive land purchases by the federal government, with a view toward permanent ownership and long-range involvement in the local economy, may not be acceptable. To meet these objections, some program modifications might be made. For example, forestry projects might be undertaken jointly by the federal and state governments, or with state and county governments. After the improvement program is completed, the federal government might by prearrangement sell its share of the enterprise to the state and local governments; or the governmental units at all levels involved might sell their shares to local industry. Alternatively, the federal government, by appropriate measures, might induce large industrial users of forest products to undertake these programs initially. ${ }^{44}$

Another alternative might be for the federal government to lease the land on a long-term basis rather than purchase it outright; another plan might offer a choice of purchase or lease. In areas where program participation would be general enough to insure efficiency in forest restoration, participation might be made optional. Under this plan, a cooperator would agree to sell or lease his land, and in return, assuming he is employable, would be guaranteed some minimum amount of employment.

Modifications designed to increase program acceptance would of course affect the cost-benefits ratio and the distribution of benefitsfor example the optional participation plan in which the participant can sell or lease. Owners who desire employment might lease their land, while unemployable owners, and owners who wish to leave the area, might sell theirs. Cash outlays for land purchases would thus be reduced and annual rental payments would be substituted on land not purchased. Depending upon the size of annual rental payments, land costs in this program modification might be more or less than in the purchase program. However, receipts would be different also, the actual amount depending upon crop-share arrangements.

While considerable thought would be required to develop workable approaches that increase program acceptance, it is clear that there are a number of alternatives to choose from. A wise combination of several alternatives would help to assure general acceptance of forestry as a solution to the low-income problem in areas where this approach is otherwise feasible.

44 It is sometimes suggested that developing forestry as part of the farm enterprise is a more desirable alternative. While there are obvious advantages to this procedure, there are serious limitations. Restoring present woodland holdings to a state of high productivity is a long-term undertaking - a matter of decades before returns begin to cover costs. A time period of this length is far beyond the planning horizon of Appalachian farmers, whose need of income is current. Only large firms and public agencies can be expected to undertake such long-term investments. Furthermore forestry, being an extensive use of land, yields such small (private) returns per acre that holdings much larger than are presently held would be required if this enterprise were to make a substantial contribution to family income. 
(4) LAND SUITED TO FORESTRY

Most of the land in the Appalachian area is not suited to commercial agriculture, and might prove more productive if converted to forest, recreation, or some other use. ${ }^{45}$ In West Virginia it is estimated that about 11.5 million acres of privately-owned, open-country land, two-thirds of the State's total acreage, might be suitable for forestry or other non-agricultural use (Table 15). This estimate allows ample acreage for commercial farms, rural residences, and rural commercial enterprises. About 2 million of these acres are now in open land and about 9.5 million are in woodland. In the Appalachian study area, which is roughly three times the size of West Virginia, the amount of privatelyheld land suitable for forestry or other non-agricultural use might be estimated at about 33 million acres. ${ }^{46}$

\section{B. Labor Retraining and Outmigration}

Labor retraining and outmigration in the Appalachian area perhaps should be considered as two parts of a single program since many retrained men are not likely to find employment, except outside the area, and most untrained men are not likely to find it anywhere. Existing levels of unemployment suggest that retraining by itself may improve employability but will not assure employment, particularly when employment opportunities lie outside the area; therefore, retraining programs should include job placement wherever possible. A program which included retraining and job placement, or some other service that would help participants migrate, would attract a substantial number of farmers. About one-third of the low-income small farmers in the West Virginia sample expressed interest in retraining programs and job information and loan programs that would enable them to move (Table 10).

\section{Increased Welfare for the Disabled and the Retired}

Continuous outmigration over a period of many years has left the area with a disproportionate share of the old and incapacitated. Of the low-income small farmers in the West Virginia survey, one-third were over 65 years of age and almost one-third were nearing retirement age (55-64 years). Perhaps 10 per cent under 65 years were disabled to the extent that they could not take off-farm employment. Incomes of retired farmers were inadequate, and in all probability the incomes of disabled farmers are inadequate also. If some forestry projects were initiated which allowed retired and disabled individuals to sell their landholdings and employable operators to take employment, the need

45 Some of the land may have no use at the present time.

46 Not all of this acreage is suited to forestry. A small part of it is classified by the Soil Conservation Service as unsuited to woodland (land capability class VIII). Some part of it, otherwise suited to forestry, is so grown up with brush and worthless trees as to make conversion to forest production economically not feasibie. 


\section{TABLE 15. Estimation of West Virginia Acreage Suitable for Forestry or Other Non-Agricultural Use}

\begin{tabular}{lr}
\hline \hline & 1,000 acres \\
\hline Total land area & $15,410.3^{\mathrm{n}}$ \\
Federal land & $935.0^{\mathrm{n}}$ \\
Urban and built-up areas & $433.2^{\mathrm{a}}$ \\
Water areas & \\
Privately-owned, open-country land & $68.1^{\mathrm{a}}$ \\
Land suitable for agricultural use & $13,974.0^{\mathrm{c}}$ \\
Land for rural residences, commercial use, etc. & $1,448.9^{\mathrm{d}}$ \\
Land suitable for forestry or other non-agricultural use & $927.6^{\mathrm{e}}$ \\
Open Land & $11,597.5^{\mathrm{p}}$ \\
Woodland & $2,098.6^{\mathrm{g}}$ \\
\hline
\end{tabular}

a West Virginia Conservation Needs Committee, State Soil Conservation Committee, West Virginia Soil and Water Conservation Needs Inventory, 1961, p. 7.

b Includes areas of less than 40 acres and streams less than 1/8-mile wide; water areas of 40 or more acres and streams $1 / 8$-mile or wider are not incluced in total land areas.

c Total land area less federal land, urban and built-up areas and water areas.

d This estimate assumes 6,531 farms (from Table 7) with crop and pasture land equal to the average for West Virginia farms grossing $\$ 5,000$ or nore in 1959 according to the Census of Agriculture.

Number of rural nonfarm households times three acres. The number of rural nonfarm households was assumed to be equal to the number of nonfarm rural households recorded by the $U$ nited States Census of Population for 1960, plus the number of farms, using the 1954 Census definition and adjusted for underreporting, that grossed less than \$5,000 according to the Census of Agriculture for 1959 .

1959 . Privately-owned, open-country land, minus land suitable for agricultural use and land for rural residences, commercial use, etc.

The amount of open land was estimated by subtracting crop, pasture, and estimated farmstead acreage and estimated rural residence acreage from the total of cropland, pasture land, and other land in West Virginia as estimated by the West Virginia Conservation Needs Committee, State Soil Conservation Committee and recorded in West Virginia Soil and Water Conservation Needs Inventory, p. 7. open.

$\mathrm{h}$ The amount of woodland is that part of the land available for forest improvement that is not

for welfare programs in the project areas would be substantially reduced. In other areas, however, the need would remain high. At the present time the federal food surplus distribution program supplements, to some extent, the incomes of families of the old, the disabled, and the unemployed in the area. A medical care program for the aged would give further aid to that group.

\section{Improved Educational System for School-Age Youth}

Opportunities for employment in the Appalachian area will not be sufficient to meet the needs of Appalachian youth for some time to come. In the past, lack of job opportunity has resulted in a continuous stream of youthful outmigration. At the present time the high rate of unemployment in the area and the inability of depressed areas to attract industry suggest that outmigration will continue.

The problem of obtaining employment for farm youth is particularly acute because opportunities to farm in the Appalachian area are shrinking rapidly and because the unskilled labor pool in industry, into which farm youth move, is already overfull. The changing structure of the economy through time, requiring fewer unskilled workers and more skilled, managerial and professional workers, is worsening the situation. 
Employment is becoming increasingly dependent upon education. Thus, if Appalachian farm youth are to compete successfully in the national job market, they must be given at least equal educational opportunity.

If educational opportunity can be measured by achievement, Appalachian youth now have less than equal opportunity. A recent study shows that typically Appalachian West Virginia pupils are performing well below national norms. ${ }^{47}$ That study presents the following data:

\begin{tabular}{|c|c|c|c|}
\hline Grade & $\begin{array}{c}\text { National } \\
\text { Norm }\end{array}$ & $\begin{array}{c}\text { West Virginia } \\
\text { Expectancy }\end{array}$ & $\begin{array}{l}\text { West Virginia } \\
\text { Achievement }\end{array}$ \\
\hline 3 (April) & 3.7 & 3.4 & 3.2 \\
\hline 6 (April) & 6.7 & 6.2 & 5.4 \\
\hline 9 (April) & 9.7 & 9.0 & 7.8 \\
\hline \multicolumn{4}{|l|}{12} \\
\hline Science & 50 & 35 & 39 \\
\hline English & 50 & 40 & 31 \\
\hline Mathematics & 50 & 33 & 43 \\
\hline Social Studies & 50 & 33 & 25 \\
\hline
\end{tabular}

Data for grades 3 through 9 are expressed in terms of grade levels and for grade 12 in terms of percentiles. Achievement is compared with two standards, national norms and West Virginia expectancies. Expectancy refers to the national achievement norm adjusted for general intelligence. I.Q. scores for West Virginia pupils averaged about 5 points lower than the national average for each grade. Near the end of grade 3 , achievement of West Virginia pupils is already below expectancy and half a grade below the national norm. Near the end of grade 6, achievement has fallen more than half a grade below expectancy and more than a whole grade below the national norm. Near the end of grade 9 , West Virginia pupils are more than a whole grade behind their own expectancy and almost two grades behind ninth-graders over the nation. In grade 12, West Virginia pupils failed to achieve national norms in the four subjects tested, although they exceeded expectations in two subjects-science and mathematics.

Improving the educational opportunities of Appalachian youth will require increased expenditures for education. While it is true that this will not automatically lead to an improved educational system, it is equally true that a dearth of funds will prevent improvement. Expenditures for education in West Virginia, for example, are now substantially below the United States average (Table 16). Nationally, current expenditures per pupil are 50 per cent higher than in West Virginia, and

47 Legislative Interim Committee, State of West Virginia, A Survey of the Educational Programs of the West Virginia Public Schools (The Survey Staff, E. K. Feaster, Director), 1957, pp. XVII-XVIII. 
expenditures for capital outlay per pupil are more than three times as large. To increase total per pupil expenditures in West Virginia to equal those nationally would require an increase of $\$ 181$ per pupil per year. Since 460,000 students are enrolled in public schools in West Virginia, ${ }^{48}$ expenditures would have to increase by over $\$ 80$ million. This amount, or even a fraction of it, would be a difficult new burden to undertake since incomes in the State already are low. Personal income per schoolage child in 1957-58 was $\$ 8,662$ for the United States, but it was only $\$ 5,854$ for West Virginia. Although 2.91 per cent of the personal income in the United States was spent on public education, in West Virginia it was 3.14 per cent. ${ }^{49}$ These data suggest that a general upgrading of public education in West Virginia and in the Appalachian area would require federal aid.

In addition to overall improvement of the educational system, there is need for a shift in emphasis. Since opportunities in agriculture are extremely limited, it would seem wise to terminate much of the training in vocational agriculture and direct it toward job areas of greatest employment potential. How much nonfarm vocational training should be substituted for vocational agriculture courses now taught is open to question. Many of the skills needed in industry are so specialized that they cannot be taught in the usual high school. However, some that can be taught will be obsolete by the time the trained student enters the labor force. Perhaps this suggests a higher quality of general educationeducation that will provide the student with the mental tools for learning needed skills on the job, and for adapting himself to the more urban environment into which he will move.

Appalachian farmers would apparently look with favor upon some of the suggested changes. In the West Virginia survey, three-fourths were in favor of federal aid to the local schools. Three-fourths believed that vocational training for nonfarm employment was as important or more important than training in agriculture. Ninety-five per cent thought that young people needed at least a high school education.

48 U. S. Department of Health, Education and Welfare, Office of Education, Preliminary Statistics of State School Systems, 1959-1960, Circular No. 663 (Washington: Government Printing Office, 1961) p. 6.

49 Data are from Samuel Schloss and Carol Joy Hobson, "Statistics of State School Systems; 1957-58, Organization, Staff, Pupils, and Finances," Biennial Survey of Education in the United States, 1956-58. OE-20020-58, Chapter 2, U. S. Department of Health, Education and Welfare, Office of Education. The public school system includes all public full-time elementary and secondary schools. Dollar values are rounded. 

APPENDIX 
APPENDIX TABLE 1. Comparison of the Distributions of Farms and Farm Operators in West Virginia and the Appalachian Area with Respect to Gross Farm Sales, Days Worked Off-Farm by Operator, and Age of Operator, 1954 Census of Agriculture

\begin{tabular}{|c|c|c|c|c|}
\hline \multirow[b]{2}{*}{ Item } & \multicolumn{2}{|c|}{ West Virgini? } & \multicolumn{2}{|c|}{ Appalachian area } \\
\hline & $\begin{array}{c}\text { No. of farms } \\
\text { or farm } \\
\text { operators }\end{array}$ & $\begin{array}{c}\text { Distribution } \\
\text { (per cent) }\end{array}$ & $\begin{array}{c}\text { No. of farins } \\
\text { or farm } \\
\text { operators }\end{array}$ & $\begin{array}{c}\text { Distribution } \\
\text { (per cent) }\end{array}$ \\
\hline $\begin{array}{c}\text { Annual gross farm sales } \\
\$ 25,000 \text { and over }\end{array}$ & 350 & 0.5 & 873 & 0.3 \\
\hline $10,000-24,999$ & 1,158 & 1.7 & 3,224 & 1.2 \\
\hline 5,000-9,999 & 2,264 & 3.3 & 6,450 & 2.4 \\
\hline $2,500-4,999$ & 3,139 & 4.6 & 14,323 & 5.3 \\
\hline $1,200-2,499$ & 5,737 & 8.4 & 33,235 & 12.4 \\
\hline $250-1,199$ & 20,887 & 30.5 & 91,890 & 34.4 \\
\hline Less than 250 & 35,018 & 51.0 & 118,192 & 44.1 \\
\hline Total $^{\mathbf{a} b}$ & 68,553 & 100.0 & 267,188 & 100.1 \\
\hline $\begin{array}{l}\text { Off-farm work by } \\
\text { operator, days }\end{array}$ & & & & \\
\hline 0 & 27,407 & 41.1 & 121,635 & 45.9 \\
\hline $1-99$ & 9,743 & 14.6 & 41,073 & 15.5 \\
\hline 100 or more & 29,517 & 44.3 & 102,101 & 38.6 \\
\hline Total $^{\mathrm{a} \mathbf{b}}$ & 66,667 & 100.0 & 264,809 & 100.0 \\
\hline $\begin{array}{l}\text { Age of operator, years } \\
\text { Under } 25\end{array}$ & 591 & 0.9 & 1864 & 17 \\
\hline $25-34$ & 6,075 & 9.0 & 10,313 & 9.4 \\
\hline $35-44$ & 14,146 & 20.8 & 22,013 & 20.0 \\
\hline $45-54$ & 16,342 & 24.1 & 26,195 & 23.8 \\
\hline $55-64$ & 14,265 & 21.0 & 25,122 & 22.8 \\
\hline 65 and over & 16,422 & 24.2 & 24,719 & 22.4 \\
\hline Total $^{\mathrm{a}} \mathrm{b}$ & 67,841 & 100.0 & 110,226 & 100.1 \\
\hline
\end{tabular}

a Totals do not always agree due to varying rates of reporting.

b Percentages do not always total to 100.0 due to rounding.

c The 1954 Census of Agriculture records the age distributions of farmers at two levels of aggregation: all farmers by states and commercial farmers by subregions. This comparison, therefore, is between all farmers in West Virginia and commercial farmers in the Appalachian area. 
APPENDIX TABLE 2. Procedure for Calculating Average Net Income of West Virginia Farmers

\begin{tabular}{|c|c|c|c|}
\hline Item & 1956 & 1957 & 1958 \\
\hline $\begin{array}{l}\text { 1. Average net income from farming, } \\
\text { West Virginia farm operators }{ }^{\mathrm{a}}\end{array}$ & $\$ 831$ & $\$ 716$ & $\$ 904$ \\
\hline $\begin{array}{l}\text { 2. Average cash receipts from farm marketings, } \\
\text { West Virginia farm operators }{ }^{b}\end{array}$ & 1,526 & 1,667 & 1,784 \\
\hline $\begin{array}{l}\text { 3. Estimated average cash receipts from farm market- } \\
\text { ings, sample of West Virginia open-country } \\
\text { farm operators }\end{array}$ & $2,133^{d}$ & & \\
\hline $\begin{array}{l}\text { 4. Estimated cash receipts from farm marketings, } \\
\text { West Virginia open-country farm operators }{ }^{\text {e }}\end{array}$ & 2,133 & 2,330 & 2,494 \\
\hline $\begin{array}{l}\text { 5. Estimated average net income from farming, } \\
\text { West Virginia open-country farm operators }\end{array}$ & 1,162 & 1,001 & 1,264 \\
\hline $\begin{array}{l}\text { 6. Estimated average income from off-farm work, } \\
\text { West Virginia open-country farm operators }\end{array}$ & $1,540^{g}$ & $1,493^{\mathrm{h}}$ & $1,396^{\mathrm{h}}$ \\
\hline $\begin{array}{l}\text { 7. Estimated average income from transfer payments } \\
\text { and nonfarm investment, West Virginia open- } \\
\text { county farm operators }\end{array}$ & $409^{1}$ & $467^{\mathrm{h}}$ & $503^{\mathrm{h}}$ \\
\hline $\begin{array}{l}\text { 8. Estimated average income from off-farm sources, } \\
\text { West Virginia open-country farm operators } \\
\text { (line } 6+\text { line } 7 \text { ) }\end{array}$ & 1,949 & 1,960 & 1,899 \\
\hline $\begin{array}{l}\text { 9. Estimated average net income, West Virginia } \\
\text { farm operators }{ }^{\text {jx }}\end{array}$ & 3,111 & 2,961 & 3,163 \\
\hline
\end{tabular}

a U. S. Department of Agriculture, The Farm Income Situation, F15 175, September 1959, p. 17.

b "State Estimates of Farm Income, 1949-59," a supplement to the July 1960 issue of The Farm Income Situation, August 1960, and "Number of Farms by States, 1910-56 and 1957-58," November 1957 and March, 1959.

c The 757 farm-operator sample survey average was $\$ 2,215$ for the period June 1, 1956 to May 31, 1957. This value was adjusted to the 1956 calendar year on the basis of the relation between average receipts for all farmers in 1956 and 1957 in line 2.

d This estimate may be too high in view of the fact that open-country farmers make up at least 10 per cent of all farmers whose average receipts were $\$ 1,526$.

- These amounts were calculated on the assumption that year-to-year receipts varied about the base year (1956) by the same proportion for open-country farmers as for all West Virginia farmers.

These amounts were calculated on the assumption that receipts and net income from farming bore the same relation to each other for open-country farmers as for all West Virginia farmers.

g The 1956 estimate was obtained by adjusting average off-farm income for the period June 1, 1956, to May 31, 1957, from the sample survey of 757 farm operators. The adjustment was made on the assumption that off-farm work income varied annualiy with employment levels in nonagricultural establisimments in West Virginia (reported in Statistical Abstract of the United States, 1958, p. 214).

h Average value for the 469 farm-operator sample survey.

1 The amount for 1956 from the 1957 farm-operator sample survey was adjusted upward on the basis of a more complete enumeration of transfer payments and nonfarm investment income made in the 469 farm-operator sample survey.

1 There may be some upward bias in these estimates due to the overestimate of income from farming (see footnoted).

$\mathbf{k}$ Average net income for open-country farmers is assumed to equal that of all farmers. Opencountry farmers earn more from farming and less from off-farm employment. Since these factors tend to offset each other and since perhaps 85 to 90 per cent of all farmers are in the open country, the two groups might be expected to earn about the same income from all sources. 
APPENDIX TABLE 3. Procedure for Calculating Average Net Income of United States Farmers

\begin{tabular}{ll|r|r|r}
\hline \multicolumn{1}{c|}{ Item } & \multicolumn{1}{c|}{1956} & \multicolumn{1}{c|}{1957} & \multicolumn{1}{c}{1958} \\
\hline 1. Average net income of all farmers from farming ${ }^{\mathrm{a}}-$ - $^{-}$ & $\$ 2,338$ & $\$ 2,426$ & $\$ 2,952$ \\
2. Estimated average off-farm income of all farmers ${ }^{-}$ & 1,348 & 1,359 & 1,348 \\
3. Estimated average net income of all farmers & 3,686 & 3,785 & 4,300 \\
\hline
\end{tabular}

a U. S. Department of Agriculture, "State Estimates of Farm Income 1949-59," a supplement to the July 1960 issue of The Farm Income Situation, August 1960, p. 9.

b The amounts in line 2 were obtained by dividing the annual net income of the farm population from non-agricultural sources by the number of farms in the relevant years. These data are reported in Farm Income Situation for July 1960, pp. 34, 40.

\section{APPENDIX TABLE 4. Procedure for Calculating Average Net Income of United States Commercial Farmers}

\begin{tabular}{|c|c|c|c|c|}
\hline Item & 949 & 1956 & 1957 & 1958 \\
\hline $\begin{array}{l}\text { Average net income of all farmers from } \\
\text { farming }^{\mathrm{a}}\end{array}$ & \multirow{5}{*}{$\begin{array}{r}\$ 2,259 \\
2,822 \\
2,822 \\
740\end{array}$} & \multirow[t]{2}{*}{$\$ 2,338$} & \multirow[t]{2}{*}{$\$ 2,426$} & \multirow[t]{2}{*}{$\$ 2,952$} \\
\hline $\begin{array}{l}\text { 2. Average net income of commercial farmers } \\
\text { from farming }\end{array}$ & & & & \\
\hline $\begin{array}{l}\text { 3. Estimated average net income of commercial } \\
\text { farmers from farming }{ }^{c}\end{array}$ & & 2,835 & 2,657 & 3,688 \\
\hline 4. Estimated off-farm income ${ }^{d}$ & & 928 & 936 & 928 \\
\hline $\begin{array}{l}\text { 5. Estimated average net income of } \\
\text { farmers (line } 3+\text { line } 4 \text { ) }\end{array}$ & & 3,763 & 3,593 & 4,616 \\
\hline
\end{tabular}

a U. S. Department of Agriculture, "State Estimates of Farm Income 1949-59," a supplement to the July issue of The Farm Income Situation, August 1960, p. 9.

b Ernest W. Grove, "Per Capita Income by Economic Class of Farm, 1949," Agricultural Economics Research, Vol. VIII, No. 2, April 1956, p. 53, col. 6.

c These amounts were calculated on the assumption that year-to-year net income from farming varied about the base year (1949) by the same proportion for commercial farmers as for all farmers.

d The amounts in line 4 were obtained by the same procedure described for line 3 . Off-farm income to commercial farmers for 1949 is reported in Agricultural Economics Research, April 1956, p. 53. Other data required for this calculation, annual net income of the farm population from non-agricultural sources and number of farms, are reported in The Farm Income Situatlon for July 1960 , p. 34 and p. 40 , col. 1 .

\section{Construction of Modified Farm-Operator Family Level-of-Living Index for Counties of the U. S.}

A modified farm-operator family level-of-living index was developed using the statistical techniques employed in constructing the U. S. Department of Agriculture's index.' The index formula developed by workers in the Department of Agriculture was constructed from county data in the 1945 Census on four items which previous research had shown to be related to level of living. Factor analysis was used to weight the items and appropriate statistical techniques were then applied to make the scores more conventional. The U. S. Department of Agriculture's formula in final form is:

1 This technique is described in Margaret Jarman Hagood and Daniel O. Price, Statistics for Soclologists, Revised Edition (New York: Henry Holt and Co., 1952) pp. 526-530, 537-541. 
when

$\mathrm{I}_{1064}=.538 \mathrm{X}_{1}+.603 \mathrm{X}_{2}+.617 \mathrm{X}_{8}+.275 \mathrm{X}_{4}$

$\mathrm{X}_{1}=$ per cent of farms with electricity

$\mathrm{X}_{2}=$ per cent of farms with telephones

$\mathrm{X}_{3}=$ per cent of farms with automobiles

$\mathrm{X}_{4}=$ average value of products sold or traded, in hundreds of dollars.

The modified formula developed in the present study was constructed from county data in the 1954 Census on seven items which were assumed to be related to level of living. In addition to per cent of farms with electricity, with telephones and with automobiles, were per cent of farms with television sets, piped running water, home freezers, and motor trucks. Factor analysis was used to select the items most highly correlated with level of living as well as to weight these items. The modified formula in final form is:

when

$$
\mathrm{I}_{1054}=.356 \mathrm{X}_{1}+.422 \mathrm{X}_{2}+.624 \mathrm{X}_{3}+.493 \mathrm{X}_{4}
$$

$\mathrm{X}_{1}=$ per cent of farms with telephones

$\mathrm{X}_{3}=$ per cent of farms with piped running water

$\mathrm{X}_{3}=$ per cent of farms with home freezers

$\mathrm{X}=$ per cent of farms with automobiles.

The two formulas have two items in common-per cent of farms with telephones and with automobiles. In the modified formula per cent of farms with piped running water and per cent of farms with home freezers substitute for per cent of farms with electricity and average value of products sold or traded. The former item failed in the process of factor analysis to correlate well with level of living ("first factor") presumably because by 1954 most farmers had electricity and hence this item had lost its discriminating power. The latter item was excluded from consideration because it was believed to be the item that biased (downward) the level-of-living scores for Appalachian farmers.

The index used by the U. S. Department of Agriculture and the index developed in this study yield similar results. When the level-ofliving score for the average U.S. county is set at 100 , the two indexes yield 64 and 57, respectively, as scores for the Appalachian area. 


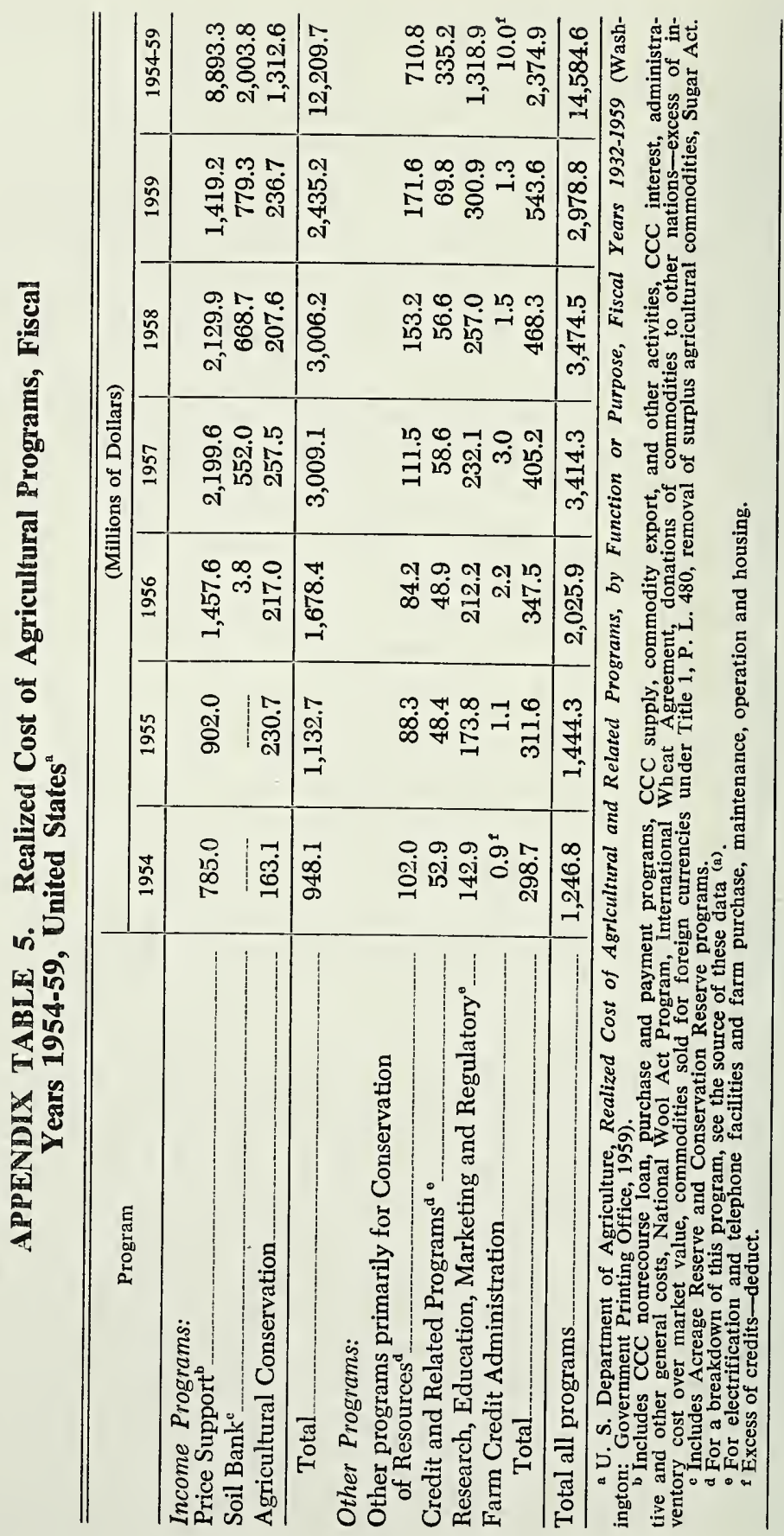




\section{Calculation of Indirect Income Effects of Farm Programs: Estimation of Commodities Purchased}

Estimates of purchases were limited to price-supported commodities used in Appalachian farm production-feed grains and the edible feed by-products of other commodities. ${ }^{2}$ Estimates were based on data from three sources: the Bureau of the Census, the Crop Reporting Service, and Southern States Cooperative, a feed manufacturing firm.

The estimating procedure consisted of five steps:

1. Average expenditure per Appalachian farm was estimated for grains and grain by-products, protein feeds, commercial mixed feeds, and supplements for poultry, dairy, hogs, and other livestock. This estimate was made by interpolating these item expenditures for farmers in the South Atlantic and the East South Central regions of the United States as reported in Farmer's Expenditures in 1955 by Regions. ${ }^{3}$ The Appalachian area lies in these two regions and the interpolation was made on the basis of the proportion of farms lying in each.

2. Average per farm item expenditures were multiplied by the number of Appalachian farms in 1954 to yield Appalachian expenditures for each of these feed items.

3. Since these estimates of item expenditures were desired for 1954 rather than 1955 they were adjusted to 1954 by multiplying each item expenditure by the ratio of 1954 to 1955 total feed expenditures. ${ }^{4}$

4. Item expenditures were divided by prices Appalachian farmers paid for these items in 1954. This calculation converted expenditures into quantities purchased.

5. Since some of the items were in the form of commercially mixed feeds, the further step of breaking these down into their component parts was necessary. This was accomplished by means of commercial feed formulas used in 1954 in the Appalachian area by a major feed manufacturing firm, Southern States Cooperative, Inc. The number of pounds of a component feed was obtained by multiplying the number of pounds of that feed in a hundredweight of commercial feed by the number of hundredweights purchased. This was done for each of the component feeds in each of the kinds of commercially mixed feeds. Amounts of each kind of component feed were totaled and these totals added to the amounts of feeds purchased unmixed to yield grand totals of each of the feed commodities and their by-products. The grand totals were divided by appropriate numbers to yield bushels, hundredweights or tons of commodity or by-product purchased by Appalachian farmers in 1954.

2 Non-feed inputs were considered too minor to be included here; linseed oil and turpentine (gum naval stores) for use in paints are examples.

3 U. S. Department of Agriculture and U. S. Department of Commerce, U. S. Department of Agriculture Statistical Bulletin No. 224, April 1958, p. 126.

4 Feed expenditures for 1954 are from the Census of Agriculture. 


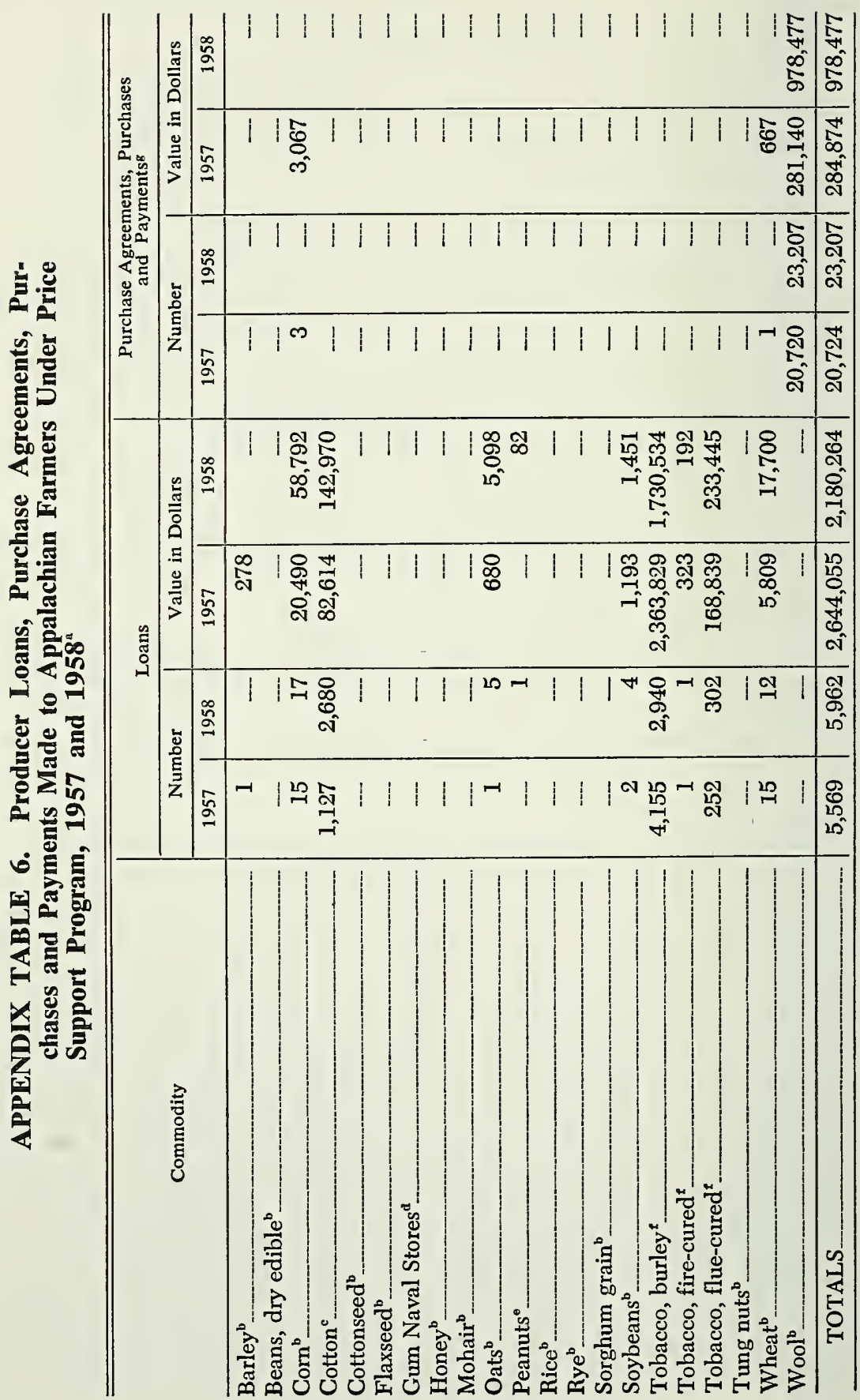




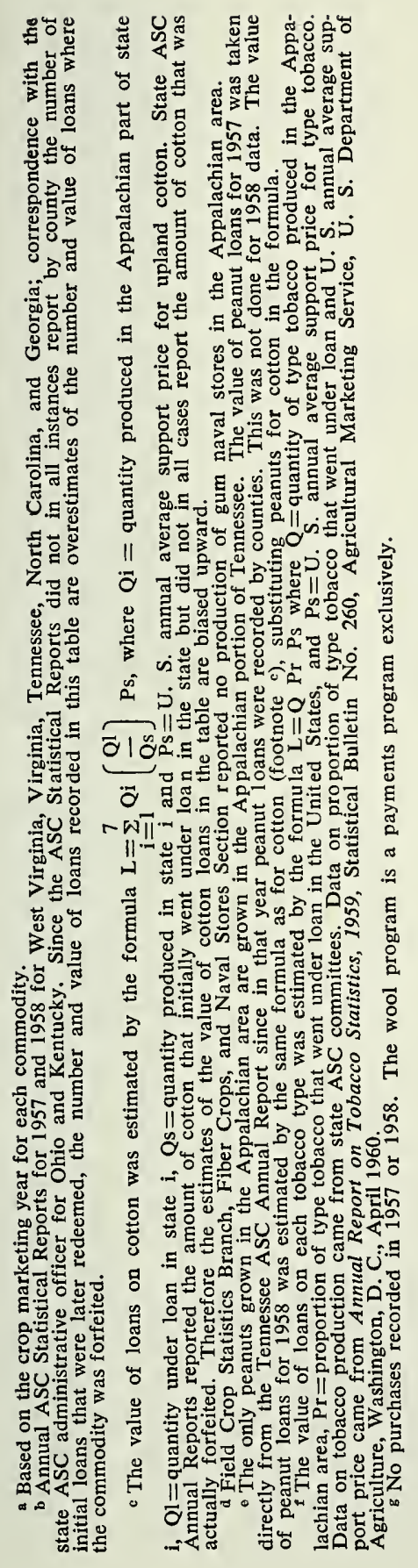


APPENDIX TARLE 7. Livestock and Land Inventory, Physical Output and Value of Output for Budgeted Dairy Farm and Beef-Sheep Farm, Appalachian Area ${ }^{a}$

\begin{tabular}{|c|c|c|}
\hline Item & Dairy Farmb & \\
\hline \multirow[t]{2}{*}{$\begin{array}{l}\text { 1. Livestock } \\
\text { Inventory }\end{array}$} & Number & Item \\
\hline & $\begin{array}{r}35 \\
9 \\
6\end{array}$ & $\begin{array}{l}\text { Holstein dairy cows } \\
\text { heifer replacements } \\
\text { calf replacements }\end{array}$ \\
\hline \multirow[t]{3}{*}{$\begin{array}{l}\text { 2. Land } \\
\text { Inventory }\end{array}$} & $\begin{array}{l}\text { Number } \\
\text { (acres) }\end{array}$ & Item \\
\hline & $\begin{array}{l}90 \\
46 \\
\end{array}$ & $\begin{array}{l}\text { improved permanent pasture } \\
\text { cropland }\end{array}$ \\
\hline & 136 & Total \\
\hline
\end{tabular}

3. Output:

Physical

Quantities

and Value

\begin{tabular}{|c|c|c|c|c|c|}
\hline Number & Item & $\begin{array}{l}\text { Average } \\
\text { Yield } \\
\text { (lbs.) }\end{array}$ & $\begin{array}{c}\text { Total } \\
\text { Produc- } \\
\text { tion }\end{array}$ & Pricec & $\begin{array}{l}\text { Total } \\
\text { Value }\end{array}$ \\
\hline 35 & $\begin{array}{l}\text { Grade } \\
\text { B milk }\end{array}$ & $\begin{array}{l}10,000 \\
(3.8 \%) \\
\text { butter- } \\
\text { fat }\end{array}$ & $\begin{array}{c}3,500.0 \\
\text { cwt. }\end{array}$ & $\begin{array}{c}\$ 2.88 \\
\text { cwt. }\end{array}$ & $\$ 10,080$ \\
\hline 8.2 & Cull & & & 110.00 & 902 \\
\hline 3.8 & $\begin{array}{l}\text { cows } \\
\text { Cull } \\
\text { heifers } \\
\text { ( } 18 \mathrm{mo} \text {. } \\
\text { old) }\end{array}$ & 800 & $\begin{array}{l}30.4 \\
\text { cwt. }\end{array}$ & $\begin{array}{l}\text { cow } \\
25.00 \\
\text { cwt. }\end{array}$ & 760 \\
\hline 3.5 & Cull & 350 & 12.25 & 25.00 & 306 \\
\hline 16.1 & $\begin{array}{l}\text { calves } \\
\text { Male calves } \\
\text { within week }\end{array}$ & $\begin{array}{l}\text { sold } \\
\text { of birth }\end{array}$ & cwt. & $\begin{array}{l}\text { cwt. } \\
10.00 \\
\text { calf }\end{array}$ & 161 \\
\hline
\end{tabular}

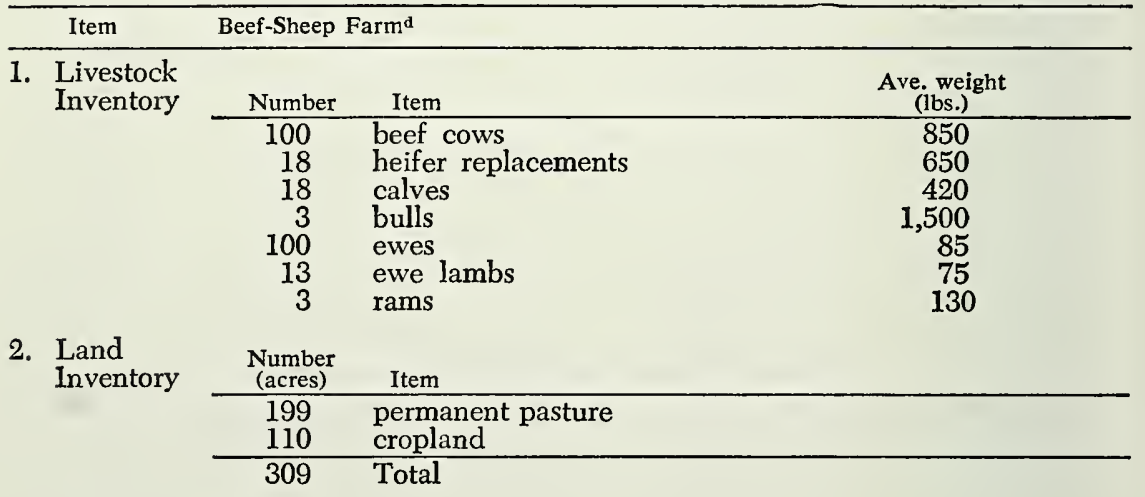




\section{APPENDIX TABLE 7. (Continued)}

3. Output:

Physical

Quantities and Value

\begin{tabular}{|c|c|c|c|c|c|}
\hline Number & Item & $\begin{array}{c}\text { Average } \\
\text { Yield } \\
\text { (1bs.) } \\
\end{array}$ & $\begin{array}{c}\text { Total } \\
\text { Produc- } \\
\text { tion } \\
\end{array}$ & Price & $\begin{array}{l}\text { Total } \\
\text { Value } \\
\end{array}$ \\
\hline 68 & Calves & 420 & 285.6 & $\$ 22.20$ & $\$ 6,340.32$ \\
\hline 18 & Cull & 850 & $\begin{array}{l}\text { cwt. } \\
153.0\end{array}$ & $\begin{array}{l}\text { cwt. } \\
17.30\end{array}$ & $2,646.90$ \\
\hline 115 & $\begin{array}{l}\text { cows } \\
\text { Lambs }\end{array}$ & 75 & $\begin{array}{l}\text { cwt. } \\
862.5\end{array}$ & $\begin{array}{l}\text { cwt. } \\
20.50\end{array}$ & $1,768.13$ \\
\hline 13 & $\begin{array}{l}\text { Cull } \\
\text { ewes }\end{array}$ & 85 & $\begin{array}{l}11.05 \\
\text { cwt. }\end{array}$ & $\begin{array}{l}7.00 \\
\text { cwt. }\end{array}$ & 77.35 \\
\hline 100 & $\begin{array}{l}\text { Fleeces } \\
\text { (ewes) }\end{array}$ & 7.5 & $\begin{array}{l}750 \\
\text { Ibs. }\end{array}$ & lb. & 382.50 \\
\hline 13 & $\begin{array}{l}\text { (Yearling } \\
\text { ewes) }\end{array}$ & 7.5 & $\begin{array}{l}97.5 \\
\text { lbs. }\end{array}$ & $\begin{array}{l}.51 \\
\text { lb. }\end{array}$ & 49.73 \\
\hline 3 & (Rams) & 9.0 & $\begin{array}{l}27.0 \\
\text { lbs. }\end{array}$ & lb. & 13.77 \\
\hline
\end{tabular}

TOTAL VALUE.

$\$ 11,278.69$ used.

\& The data are based on the assumption that modern production methods and techniques are

b The dairy farm was budgeted by an interdepartmental committee of the Division of Agriculture, West Virginia University.

c For the most part, long-term normal prices were used. These are published in Agricultural Price and Cost Projections, (for official use only), Agricultural Research Service-Agricultural Marketing Service, U. S. Department of Agriculture, September 1957.

The beef-sheep farm was budgeted by the author in consultation with members of the Department of Animal Husbandry and the Department of Agronomy, West Virginia University.

\section{Incomes of Elderly Families in the 1959 West Virginia Survey}

Appalachian farm family income was considered low if less than $\$ 4,000$. Because needs of elderly families ${ }^{5}$ are fewer, acceptable living levels can be maintained with less income. A "modest but adequate" level of living was assumed to be within reach of single retired individuals with incomes of $\$ 1,500$ and retired couples with incomes of $\$ 2,100$. Large families were assumed to require $\$ 600$ more income for each additional member, until a maximum of $\$ 4,000$ was reached.

On the basis of this schedule most of the incomes of elderly families in the West Virginia survey were inadequate (Appendix Table 8). Incomes of two-thirds of the families were seriously inadequate in that they were less than two-thirds of the required minimums. One-fourth had inadequate incomes and only one-eighth had adequate incomes.

The seriousness of the income problem among the aged in this study appears to vary directly with size of family. While some 1-to-4-member families had adequate incomes, none of the 5-to-7-member families had adequate incomes. While some 1-to-5-member families had adequate incomes, some inadequate and some seriously inadequate, almost all 6-to-7-member families had seriously inadequate incomes.

5 Families whose heads are 65 years of age or over. 
Elderly farm families may be larger in the Appalachian area than in the United States generally. In the West Virginia survey, 49 per cent were 1-to-2-member families; 23 per cent were 3-member families; and 28 per cent were 4-or-more-member families; in a nationwide survey conducted in 1956, the figures were 72 per cent, 14 per cent, and 14 per cent, respectively. ${ }^{6}$ At the time of the West Virginia survey, unemployment was high in the neighboring industrial centers, and many children, who otherwise live in the industrial cities, were at home with their parents "waiting out" the recession. These "secondary families" were included as members of the older families if they had been living in their households for three months prior to the time of the survey. In some families a son or daughter feels the obligation to stay with the parents and to care for them in their declining years.

Thus the income problem of older families per se may not be as serious as the data indicate. But the income problem for households of elderly families is serious and will continue to be so until employment opportunities become available to employable members. Even when this happens, a problem remains for the aged families since half of the larger households (4-or-more-members) had incomes inadequate even for two-member families. ${ }^{7}$ If all 4-or-more-member households were reduced to three, under favorable employment conditions, three-fourths of all older families in the survey would still have an income problem. Thus, most elderly families on small farms have incomes inadequate for their needs.

A major difference in income sources between groups of families with adequate, inadequate, or seriously inadequate incomes was the proportion receiving social security benefits and the amounts received (Appendix Table 9). While 90 per cent of the families in the first group received benefits, only 68 per cent in the second, and only 51 per cent in the third did. While 54 per cent of the families in the first group received benefits amounting to $\$ 1,100$ or more annually, only 22 per cent of the second group and 9 per cent of the third group did.

6 James D. Cowhig and Emily O. Stewart in The Older Farm Family and Medical Costs, Agriculture Information Bulletin No. 235, Agricultural Marketing Service, U. S. Department of Agriculture, Washington, D. C., December 1960, p. 12.

7 Footnotec, Appendix Table 8. 


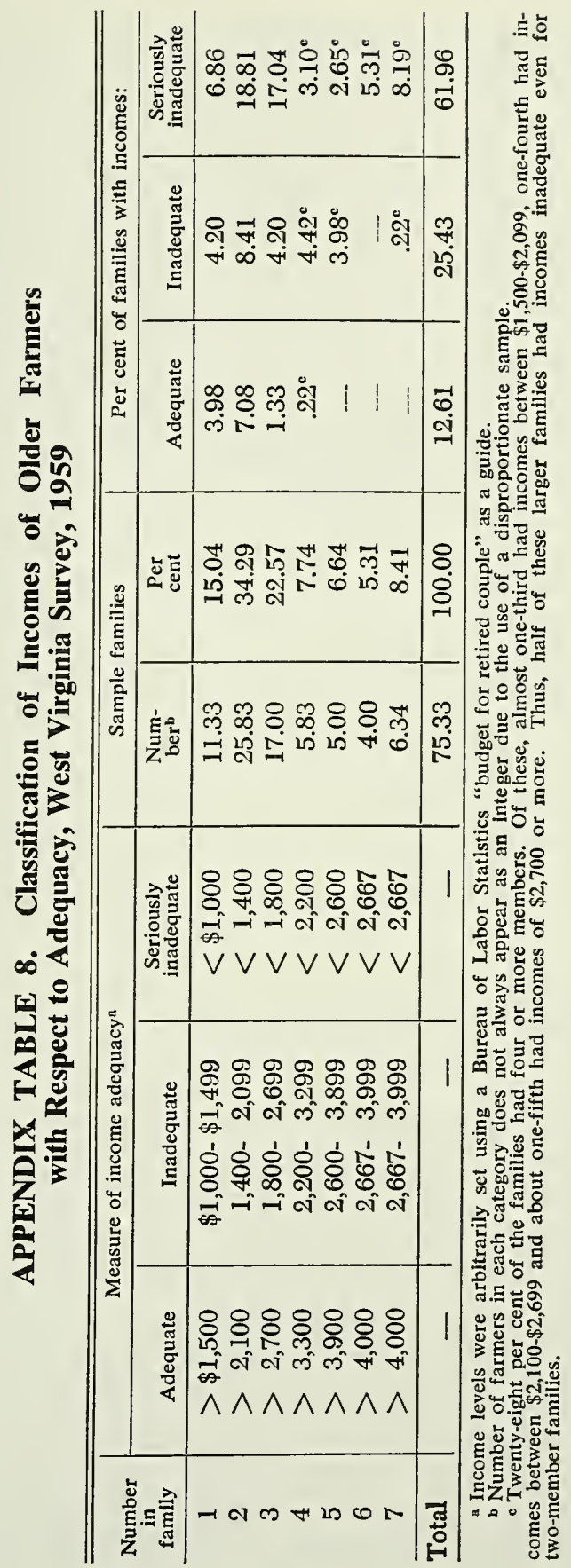


APPENDIX TABLE 9. Income Sources of Older Farmers According to Level of Income, West Virginia Survey, 1959

\begin{tabular}{|c|c|c|c|c|}
\hline \multirow[b]{2}{*}{ Item } & \multicolumn{4}{|c|}{ INCOME OF FAMILIES ${ }^{a}$} \\
\hline & $\begin{array}{c}\text { All } \\
\text { families }\end{array}$ & $\begin{array}{l}\text { Ade- } \\
\text { quate }\end{array}$ & $\begin{array}{l}\text { Inade- } \\
\text { quate }\end{array}$ & $\begin{array}{l}\text { Seriously } \\
\text { inadequate }\end{array}$ \\
\hline Number of families ${ }^{b}$ & 75.33 & 9.50 & 19.00 & 46.83 \\
\hline Social Security received benefits & $\operatorname{Per} C$ & ent of & amilies & $n$ Group \\
\hline none & 40.27 & 10.53 & 32.46 & 49.47 \\
\hline$\$ 1-\$ 499$ & 18.14 & 21.05 & 12.28 & 19.93 \\
\hline $500-1,099$ & 23.89 & 14.04 & 33.33 & 22.07 \\
\hline 1,100 or more & 17.70 & 54.39 & 21.93 & 8.54 \\
\hline Off-farm work income $(\$ 1-\$ 699)$ & 9.51 & ( & 11.40 & 10.68 \\
\hline Net rent from farm land and buildings ( $\$ 1-\$ 699)$ & 12.61 & 10.53 & 11.40 & 13.52 \\
\hline Interest and dividends ( $\$ 1-\$ 1,100$ and over $)$ & 11.06 & 31.58 & 6.14 & 8.90 \\
\hline $\begin{array}{l}\text { Royalties from coal, oil or gas }(\$ 1-\$ 1,100 \\
\text { and over) }\end{array}$ & 17.04 & 22.81 & 23.68 & 13.17 \\
\hline Unemployment compensation & - & $\ldots$ & -- & - \\
\hline $\begin{array}{l}\text { Old age pension, aid to blind, etc. } \\
(\$ 1-\$ 1,100 \text { and over })\end{array}$ & 14.60 & 1.75 & 16.67 & 16.37 \\
\hline Workers compensation $(\$ 1-\$ 899)$ & 2.65 & --- & - & 4.27 \\
\hline $\begin{array}{l}\text { Military service disability benefits }(\$ 1-\$ 1,099) \\
\text { Other military service connected payments }\end{array}$ & 8.19 & 21.05 & 10.53 & 4.63 \\
\hline$(\$ 1-\$ 1,099)$ & 3.98 & & 10.53 & 2.14 \\
\hline Aid for children or other relatives $(\$ 1-\$ 899)$ & 5.97 & - & 5.26 & 7.47 \\
\hline Other nonfarm sources $(\$ 1-\$ 1,099)$ & 4.20 & $\ldots$ & -- & 6.76 \\
\hline Farm income less than $\$ 0$ & 23.89 & 10.53 & 31.58 & 25.63 \\
\hline$\$ 1-\$ 499$ & 51.55 & 77.19 & 25.44 & 54.80 \\
\hline $500-999$ & 13.72 & - & 21.93 & 13.17 \\
\hline $1,000-1,499$ & 7.96 & 10.53 & 21.05 & 2.14 \\
\hline $1,500-1,999$ & 2.88 & 1.75 & --- & 4.27 \\
\hline
\end{tabular}

a The measure of income adequacy is described in Appendlx Table 8.

b Decimals result from the fact that the data were drawn from a disproportionate sample.

Sampling

Part of the data cited in this report were compiled from two sample surveys of West Virginia farm families and one sample survey of West Virginia small farms. Information on eligibility requirements, sampling procedure, data collection, and representativeness of the samples is given in this Appendix.

\section{Sample of 757 Farm Families (1957)}

This sample survey was designed to obtain data on income and Federal Price Support Program participation from a representative group of West Virginia farm families.

To be included in the sample the family must have operated a farm in the 12 calendar months prior to the enumeration period, June-August, 1957. The 1954 Census of Agriculture definition of a farm was used. 
A farm family was defined as a group composed of the farm operator and those persons related by blood, marriage, or adoption who lived with him; the concept included single individuals who were farm operators.

Probability area sampling procedures were used to designate the areal segments to be included in the sample. The sampling rate was 1/35. The sample consisted of 393 open-country segments in 24 of the 55 counties in the State. Since incorporated towns and cities and unincorporated places meeting certain population minimums were excluded, the sample is more properly one of open-country farm-operator families in the State. Places were identified as farms by the enumerators by a "yes" answer to one of the two questions: (if more than three acres were operated) "Did you produce $\$ 150$ of farm products in addition to your garden?"; or, (if less than three acres were operated) "Did you sell at least $\$ 150$ of farm products?"

Enumerators surveyed the farm families in the sample segments in June, July, and August of 1957. In addition to completing the schedules, enumerators mapped each of the segments, locating and identifying the residences therein whether farm or nonfarm. This information was recorded on farm identification sheets. Respondents refusing to give interviews were subsequently revisited by the survey supervisor; respondents not at home were visited a total of three times before being excluded from the survey. A total of 4,190 schedules was completed, of which 757 were farm and 3,433 nonfarm. There were 18 families not at home and 11 refusals, of which 5 were farm. The farm-family refusals and the not-at-home families, assuming they were all farm families, together constitute about 2 per cent of the sample.

A comparison of the West Virginia and the sample distributionsby economic class of farm, size of farm in acres, off-farm work by operator, and age of operator-indicates that the sample is reasonably representative (Appendix Table 10). The larger distortions can be explained in part by the open-country nature of the sample. Farms in the open country tend to be larger, to sell more products, and their operators tend toward less off-farm employment. Some of the distortion can be explained by the difference in time periods under consideration. Data for West Virginia farmers are from the Census for 1954, while the sample survey was made for the year ending May 13, 1957. And finally, census data are based on a 10 per cent under-enumeration of farms which might result in a non-open-country bias since the under-enumeration may very likely occur in the more isolated areas. ${ }^{\circ}$

8 The Crop Reporting Board (in "Number of farms by States, 1910-56, Revised Estimates," SpSy 3(57)) estimated 76,000 farms in West Virginia in 1954 while the Census of Agriculture for that year recorded 68,583 . 
APPENDIX TABLE 10. A Comparison of the Distributions of Farms and Farm Operators of West Virginia and a Sample Survey of 757 Open-Country Farm-Operator Families with Respect to Economic Class of Farm, Size of Farm in Acres, Days Worked Off-Farm by Operatior, and Age of Operator, 1957

\begin{tabular}{|c|c|c|c|c|}
\hline \multirow[b]{2}{*}{ Item } & \multicolumn{2}{|c|}{ WEST VIRGINIA ${ }^{\mathrm{a}}$} & \multicolumn{2}{|c|}{ SAMPLE SURVEY } \\
\hline & $\begin{array}{c}\text { No. of farms } \\
\text { or farm } \\
\text { operators }\end{array}$ & $\begin{array}{l}\text { Distribution } \\
\text { (per cent) }\end{array}$ & $\begin{array}{c}\text { No. of farms } \\
\text { or farm } \\
\text { operators }\end{array}$ & $\begin{array}{l}\text { Distribution } \\
\text { (per cent) }\end{array}$ \\
\hline $\begin{array}{l}\text { Economic class of farm } \\
\text { I-III } \\
\text { IV } \\
\text { V VI } \\
\text { Part-time } \\
\text { Residential }\end{array}$ & $\begin{array}{r}3,772 \\
3,162 \\
5,737 \\
8,833 \\
12,039 \\
35,003\end{array}$ & $\begin{array}{r}5.4 \\
4.6 \\
8.4 \\
12.9 \\
17.6 \\
51.1\end{array}$ & $\begin{array}{r}97 \\
63 \\
113 \\
116 \\
191 \\
177\end{array}$ & $\begin{array}{r}12.8 \\
8.3 \\
15.0 \\
15.3 \\
25.2 \\
23.4\end{array}$ \\
\hline $\begin{array}{c}\text { Total }^{\mathrm{b}} \\
\text { Size of farm (acres) } \\
\text { Under } 10 \\
10-29 \\
30-49 \\
50-69 \\
70-99 \\
100-139 \\
140-179 \\
180-219 \\
220-259 \\
260-499 \\
500-999 \\
1,000 \text { and over }\end{array}$ & $\begin{array}{r}68,546 \\
\\
8,074 \\
11,211 \\
8,825 \\
8,130 \\
8,681 \\
8,486 \\
4,750 \\
3,114 \\
1,799 \\
3,811 \\
1,308 \\
394\end{array}$ & $\begin{array}{r}11.8 \\
16.4 \\
12.9 \\
11.8 \\
12.7 \\
12.4 \\
6.9 \\
4.5 \\
2.6 \\
5.5 \\
1.9 \\
0.6\end{array}$ & $\begin{array}{r}23 \\
65 \\
68 \\
77 \\
120 \\
121 \\
79 \\
64 \\
25 \\
85 \\
20 \\
10\end{array}$ & $\begin{array}{r}3.0 \\
8.6 \\
9.0 \\
10.2 \\
15.9 \\
16.0 \\
10.4 \\
8.5 \\
3.3 \\
11.2 \\
2.6 \\
1.3\end{array}$ \\
\hline $\begin{array}{l}\text { Total }^{\mathrm{b}} \\
\text { Off-farm work by } \\
\text { operator (days) } \\
0 \\
1-49 \\
50-99 \\
100-199 \\
200 \text { and over }\end{array}$ & $\begin{array}{r}27,407 \\
5,598 \\
4,145 \\
7,685 \\
21,822\end{array}$ & $\begin{array}{r}41.1 \\
8.4 \\
6.2 \\
11.5 \\
32.8\end{array}$ & $\begin{array}{r}375 \\
45 \\
32 \\
80 \\
224\end{array}$ & $\begin{array}{r}49.7 \\
6.0 \\
4.0 \\
10.6 \\
29.7\end{array}$ \\
\hline $\begin{array}{l}\text { Total }^{\mathrm{b}} \\
\text { Age of operator (years) } \\
\text { Under } 25 \\
25-34 \\
35-44 \\
45-54 \\
55-64 \\
65 \text { and over }\end{array}$ & $\begin{array}{r}66,657 \\
591 \\
6,075 \\
14,146 \\
16,342 \\
14,265 \\
14,422\end{array}$ & $\begin{array}{r}100.0 \\
\\
0.9 \\
9.0 \\
20.8 \\
24.1 \\
21.0 \\
24.2\end{array}$ & $\begin{array}{r}9 \\
63 \\
137 \\
171 \\
183 \\
193\end{array}$ & $\begin{array}{r}1.2 \\
8.3 \\
18.1 \\
22.6 \\
24.2 \\
25.6\end{array}$ \\
\hline Total $^{\mathrm{b}}$ & 67,841 & 100.0 & 756 & 100.0 \\
\hline Average age & 53.0 & & 54.3 & \\
\hline
\end{tabular}

a Census of Agriculture for 1954.

b Totals do not always agree due to varying rates of reporting. 


\section{Sample of 469 Farm Families (1959)}

This sample survey was designed to obtain data on income, attitudes, and related attributes for a representative group of West Virginia farm families.

To be included in the sample, the family in 1958 must have operated a farm as defined by the 1954 Agricultural Census. The definition of a farm family was that used in the 1957 sample.

This sample was a composite of two sub-samples. One of the subsamples consisted of 325 non-tobacco farm families drawn from the 1957 sample stratified by age. ${ }^{9}$ The other sub-sample consisted of 144 farm families drawn from a list of West Virginia tobacco farmers, stratified by county and by age. ${ }^{10}$ Within each sub-sample the number drawn from each age group corresponded with the proportion in that age group in the 1957 survey. Tobacco farmers were sampled at a rate 6 times that of non-tobacco farmers.

Since the two sub-samples were drawn using different designs, statistical estimation from the composite sample would be difficult. To reduce this difficulty, data from the tobacco sub-sample were reduced to $1 / 6$ and combined with data from the other sub-sample, and the resulting composite sample was assumed to be simple random. The data for 325 non-tobacco farmers from one sub-sample were combined with the data for 144 tobacco farmers reduced to 24 to yield, in effect, a sample of 349 families. The sample is compared with the population.

Enumerators surveyed the families in May-July of 1959. Respondents refusing to give interviews were subsequently revisited by the survey supervisor; respondents not at home were visited a total of three times before being excluded. From the 498 families drawn in the sample, 469 useable schedules were obtained. Twenty-nine schedules were not used; 17 families had moved into town or out of the county, 8 had refused interviews, and 4 were not at home. These 29 unused schedules constitute about 6 per cent of the unweighted sample.

A comparison of the West Virginia and the sample distributionsby economic class of farm, size of farm in acres, off-farm work by the operator, and age of operator-indicates that the sample is reasonably representative (Appendix Table 11).

\section{Sample of 100 Small West Virginia Farmers}

This sample survey was designed to obtain data on the kinds and amounts of agriculturally useable land in and contiguous to a representative group of West Virginia small farms.

9 The age groups were the same as those used by the agricultural censuses.

10 The list was provided by the state office of the Agricultural Stabilization and Conservation Committee and stratification was done by county ASC office personnel. 
To be included in the sample, a farm must have had total sales less than $\$ 5,000$ during the calendar year preceding the enumeration period of the first sample, June-August 1957.

Stratified simple random sampling procedures were used in drawing the sample.

The State was stratified by counties on the basis of land resource areas." The stratification showing the counties, and the number and per cent of small farms in each is recorded in Appendix Table 12.

A county or, at most two, was selected to represent each important stratum. To be selected a county had to be one which was surveyed in 1957, since this provided the geographic locations of small farms. The distribution of counties in the 1957 sample was such that one or two counties were surveyed in each of the major strata. Having selected the counties to represent the major land resource areas, the small farms to be included in this sample were drawn at random from the predominantly small-farm segments in the county, the number drawn in each county to correspond with the proportion that the small farms in that stratum made up of the State's total of small farms.

Since the object of this sample was to determine the possibility of increasing the land resources of small farms by expansion, it was necessary to exclude from the sample small farms with little or no possibility of physical enlargement. Small farms, located in segments predominated by large farms, have little possibility of expansion. If a segment had as many large as small farms, the small farms in that segment were excluded from the drawing. Following this rule, 48 farms, or 8 per cent of the small farms in the 1957 sample, were excluded from the drawing.

Through the use of the 1957 sample materials, the residences of farms in this sample were identified on county maps. Through the use of a Soils Map Legend, the soils maps (scale: 1 inch $=1320$ feet), on which the sample farms were located, were identified.

11U. S. Department of Agriculture, Soil Conservation Service, Land Resource Map of West Virginia, February 1958. 
APPENDIX TABLE 11. A Comparison of the Distributions of Farms and Farm Operators of West Virginia and a Sample Survey of 469 Open-Country Farm-Operator Families with Respect to Economic Class of Farm, Size of Farm in Acres, Days Worked Off-Farm by Operator, and Age of Operator, 1959

\begin{tabular}{|c|c|c|c|c|}
\hline \multirow[b]{2}{*}{ Item } & \multicolumn{2}{|c|}{ WEST VIRGINIA ${ }^{\mathrm{a}}$} & \multicolumn{2}{|c|}{ SAMPLE SURVEY ${ }^{b}$} \\
\hline & $\begin{array}{l}\text { No. of farms } \\
\text { or farm } \\
\text { operators }\end{array}$ & $\begin{array}{l}\text { Distribution } \\
\text { (per cent) }\end{array}$ & $\begin{array}{c}\text { No. of farms } \\
\text { or farm } \\
\text { operators }\end{array}$ & $\begin{array}{c}\text { Distribution } \\
\text { (per cent) }\end{array}$ \\
\hline $\begin{array}{l}\text { Economic class of farm } \\
\text { I-III } \\
\text { IV } \\
\text { V VI } \\
\text { Part-time } \\
\text { Residential }\end{array}$ & $\begin{array}{r}3,772 \\
3,162 \\
5,737 \\
8,833 \\
12,039 \\
35,003\end{array}$ & $\begin{array}{r}5.4 \\
4.6 \\
8.4 \\
12.9 \\
17.6 \\
51.1\end{array}$ & $\begin{array}{l}40.3 \\
25.0 \\
61.7 \\
54.0 \\
74.5 \\
93.5\end{array}$ & $\begin{array}{r}11.6 \\
7.2 \\
17.7 \\
15.5 \\
21.3 \\
26.8\end{array}$ \\
\hline $\begin{array}{c}\text { Total }^{\mathrm{c}} \\
\text { Size of farm (acres) } \\
\text { Under } 10 \\
10-29 \\
30-49 \\
50-69 \\
70-99 \\
100-139 \\
140-179 \\
180-219 \\
220-259 \\
260-499 \\
500-999 \\
1,000 \text { and over }\end{array}$ & $\begin{array}{r}68,546 \\
\\
8,074 \\
11,211 \\
8,825 \\
8,130 \\
8,681 \\
8,486 \\
4,750 \\
3,114 \\
1,799 \\
3,811 \\
1,308 \\
394 \\
\end{array}$ & $\begin{array}{r}11.8 \\
16.4 \\
12.9 \\
11.8 \\
12.7 \\
12.4 \\
6.9 \\
4.5 \\
2.6 \\
5.5 \\
1.9 \\
0.6 \\
\end{array}$ & $\begin{array}{r}349.0 \\
\\
9.8 \\
29.2 \\
31.2 \\
45.2 \\
60.0 \\
54.7 \\
35.7 \\
31.8 \\
12.0 \\
27.5 \\
7.7 \\
4.3 \\
\end{array}$ & $\begin{array}{r}100.1 \\
\\
2.8 \\
8.4 \\
8.9 \\
12.9 \\
17.2 \\
15.7 \\
10.2 \\
9.1 \\
3.4 \\
7.9 \\
2.2 \\
1.2 \\
\end{array}$ \\
\hline $\begin{array}{l}\text { Total }^{c} \\
\text { Off-farm work by } \\
\text { operator (days) } \\
0 \\
1-49 \\
50-99 \\
100-199 \\
200 \text { and over }\end{array}$ & $\begin{array}{r}27,407 \\
5,598 \\
4,145 \\
7,685 \\
21,822 \\
\end{array}$ & $\begin{array}{r}41.1 \\
8.4 \\
6.2 \\
11.5 \\
32.8 \\
\end{array}$ & $\begin{array}{r}208.2 \\
10.0 \\
14.2 \\
33.3 \\
83.3 \\
\end{array}$ & $\begin{array}{r}59.6 \\
2.9 \\
4.1 \\
9.6 \\
23.9 \\
\end{array}$ \\
\hline $\begin{array}{l}\text { Total }^{\mathrm{c}} \\
\text { Age of operator (years) } \\
\text { Under } 25 \\
25-34 \\
35-44 \\
45-54 \\
55-64 \\
65 \text { and over }\end{array}$ & $\begin{array}{r}591 \\
6,075 \\
14,146 \\
16,342 \\
14,265 \\
14,422\end{array}$ & $\begin{array}{r}100.0 \\
\\
0.9 \\
9.0 \\
20.8 \\
24.1 \\
21.0 \\
24.2 \\
\end{array}$ & $\begin{array}{r}3.5 \\
27.2 \\
60.7 \\
92.0 \\
80.8 \\
84.8 \\
\end{array}$ & $\begin{array}{r}100.1 \\
\\
1.0 \\
7.8 \\
17.4 \\
26.4 \\
23.2 \\
24.3 \\
\end{array}$ \\
\hline Total $^{\mathrm{e}}$ & 67,841 & 100.00 & 349.0 & 100.1 \\
\hline
\end{tabular}

a Census of Agriculture for 1954.

a Census of Agriculture for 1954 . Data from the sample with the higher rate was "reduced" by weighting and when combined with the data from the other sub-sample yielded in effect a sample of 349 families. Numbers of farms and farm operators are not always integers as a result. - Totals do not always agree due to varying rates of reporting; in the case of percentages to rounding. 
APPENDIX TABLE 12. Location of Farms by Land Resource Area and County, Sample of 100 Small West Virginia Farms

\begin{tabular}{|c|c|c|c|c|c|}
\hline \multirow{2}{*}{ Area and Counties ${ }^{a}$} & \multicolumn{2}{|c|}{ No. of Small Farms ${ }^{b}$} & \multirow{2}{*}{$\begin{array}{c}\text { Per cent } \\
\text { of } \\
\text { total }\end{array}$} & \multirow{2}{*}{$\begin{array}{l}\text { Representa- } \\
\text { tive } \\
\text { County }\end{array}$} & \multirow{2}{*}{$\begin{array}{l}\text { No. of } \\
\text { Farms in } \\
\text { Sample }\end{array}$} \\
\hline & County & Area & & & \\
\hline $\begin{array}{l}\text { Great Limestone Valley } \\
\text { Jefferson } \\
\text { Berkeley }\end{array}$ & $\begin{array}{l}330 \\
867 \\
\end{array}$ & 1,197 & 2 & None & $\mathbf{0}$ \\
\hline $\begin{array}{l}\text { Potomac Ridge and Valley Area } \\
\text { Morgan } \\
\text { Hampshire } \\
\text { Mineral } \\
\text { Hardy } \\
\text { Grant } \\
\text { Pendleton }\end{array}$ & $\begin{array}{r}407 \\
1,011 \\
628 \\
619 \\
505 \\
971\end{array}$ & 4,141 & 6 & $\begin{array}{l}\text { Hamp- } \\
\text { shire }\end{array}$ & 6 \\
\hline $\begin{array}{l}\text { Allegheny Mountains Steep } \\
\text { Woodland Area } \\
\text { Pocahontas } \\
\text { Greenbrier }\end{array}$ & $\begin{array}{r}939 \\
1,951\end{array}$ & 2,890 & 4 & None & 0 \\
\hline $\begin{array}{l}\text { Southern West Virginia } \\
\text { Shale Ridges } \\
\text { Monroe } \\
\text { Summers } \\
\text { Mercer }\end{array}$ & $\begin{array}{l}1,634 \\
1,454 \\
2,208\end{array}$ & 5,296 & 8 & Mercer & 8 \\
\hline $\begin{array}{l}\text { West Central Pennsylvania- } \\
\text { Northern West Virginia Plateau } \\
\text { Hancock }\end{array}$ & 235 & 235 & 1 & None & 0 \\
\hline $\begin{array}{l}\text { Tri-State Tablelands } \\
\text { Preston }\end{array}$ & 2,018 & 2,018 & 3 & Preston & 3 \\
\hline $\begin{array}{l}\text { Monongalia-Ohio Section } \\
\text { Monongalia } \\
\text { Marion } \\
\text { Harrison } \\
\text { Taylor } \\
\text { Marshall } \\
\text { Ohio } \\
\text { Brooke } \\
\text { Lewis }\end{array}$ & $\begin{array}{r}1,546 \\
1,360 \\
1,650 \\
730 \\
1,096 \\
470 \\
300 \\
1,290 \\
\end{array}$ & 8,442 & 13 & $\begin{array}{l}\text { Marion } \\
\text { Harrison } \\
\end{array}$ & $\begin{array}{r}13 \\
6\end{array}$ \\
\hline $\begin{array}{l}\text { Little Kanawha-Elk Hills } \\
\text { Clay } \\
\text { Braxton } \\
\text { Gilmer } \\
\text { Ritchie } \\
\text { Doddridge } \\
\text { Wetzel } \\
\text { Tyler } \\
\text { Calhoun } \\
\text { Kanawha }\end{array}$ & $\begin{array}{r}876 \\
1,639 \\
1,169 \\
1,169 \\
863 \\
1,181 \\
761 \\
1,280 \\
1,711\end{array}$ & 10,649 & 17 & $\begin{array}{l}\text { Clay } \\
\text { Braxton } \\
\text { Wetzel }\end{array}$ & $\begin{array}{r}5 \\
16 \\
3\end{array}$ \\
\hline $\begin{array}{l}\text { Raleigh-Fayette Plateau } \\
\text { Fayette } \\
\text { Nicholas } \\
\text { Raleigh }\end{array}$ & $\begin{array}{l}1,675 \\
1,721 \\
2,039\end{array}$ & 5,435 & 8 & Fayette & 6 \\
\hline
\end{tabular}


APPENDIX TABLE 12. (Continued)

\begin{tabular}{|c|c|c|c|c|c|}
\hline \multirow{2}{*}{ Area and Counties ${ }^{\mathrm{a}}$} & \multicolumn{2}{|c|}{ No. of Small Farms } & \multirow{2}{*}{$\begin{array}{c}\text { Per cent } \\
\text { of } \\
\text { total }\end{array}$} & \multirow{2}{*}{$\begin{array}{l}\text { Representa- } \\
\text { tive } \\
\text { County }\end{array}$} & \multirow{2}{*}{$\begin{array}{l}\text { No. of } \\
\text { Farms in } \\
\text { Sample }\end{array}$} \\
\hline & County & Area & & & \\
\hline $\begin{array}{l}\text { Chestnut Ridge Plateau } \\
\text { Tucker } \\
\text { Randolph } \\
\text { Barbour } \\
\text { Upshur } \\
\text { Webster }\end{array}$ & $\begin{array}{r}543 \\
1,238 \\
1,466 \\
1,650 \\
986 \\
\end{array}$ & 5,883 & 9 & Barbour & 9 \\
\hline $\begin{array}{l}\text { Ohio-West Virginia Foothills } \\
\text { Pleasants } \\
\text { Wood } \\
\text { Wirt } \\
\text { Roane } \\
\text { Jackson } \\
\text { Mason } \\
\text { Putnam } \\
\text { Cabell }\end{array}$ & $\begin{array}{r}395 \\
1,680 \\
490 \\
1,803 \\
1,718 \\
1,432 \\
1,466 \\
1,515\end{array}$ & 10,499 & 16 & $\begin{array}{l}\text { Mason } \\
\text { Putnam }\end{array}$ & $\begin{array}{l}8 \\
8 \\
\end{array}$ \\
\hline $\begin{array}{l}\text { Southern West Virginia Coal Fields } \\
\text { Lincoln } \\
\text { Wayne } \\
\text { Mingo } \\
\text { Logan } \\
\text { Wyoming } \\
\text { McDowell } \\
\text { Boone }\end{array}$ & $\begin{array}{r}1,700 \\
2,264 \\
940 \\
575 \\
1,091 \\
932 \\
527\end{array}$ & 8,029 & 12 & $\begin{array}{l}\text { Lincoln } \\
\text { Wayne }\end{array}$ & $\begin{array}{l}4 \\
7\end{array}$ \\
\hline Total Small Farms & & 64,714 & $99^{c}$ & & $102^{a}$ \\
\hline
\end{tabular}

a Wen a county was divided by a Land Resource Area boundary so that part of the county was in one area and part in another, the whole county was included in the area which made up the larger of the two parts. Two areas, the Northern Blue Ridge Mountains and the Greenbrier Limestone Valley were excluded from the list of areas since neither was extensive enough to include the larger part of any single county.

b Census of Agriculture for 1954.

c Does not add to 100 per cent due to rounding.

d 100 farms were used. Two farms could not be enlarged because of obstructions. 



\section{LITERATURE CITED}

Agricultural Stabilization and Conservation Statistical Reports for 1957 and 1958 for West Virginia, Virginia, Tennessee, North Carolina, and Georgia.

Barnhill, Harold E. Resource Requirements on Farms for Specified Operator Incomes. Econ. Res. Ser., U. S. D. A., Agr. Econ. Rep. No. 5. Washington: G. P. O., 1962.

Bogue, Donald J. State Economic Areas: A Description of the Procedure Used in Making a Functional Grouping of the Counties of the United States. U. S. Bureau of the Census. Washington: G. P. O., 1951.

Bogue, Donald J. and Calvin L. Beale. Farm Population, Economic Subregions of the United States. U. S. Bureau of the Census, Series Census-BAE No. 19. Washington: G. P. O., 1953.

Brandow, G. E. Interrelations Among Demands for Farm Products and Implications for Control of Market Supply. Penn State Agr. Exp. Sta., Bull. 680. University Park, Pennsylvania, 1961.

Charlottesville Research Center, Southeastern Forest Experiment Station, Division of Forest Economics. Input Data: Study of Farm Foresty Opportunities in the Southern Piedmont of Virginia (mimeo.). Asheville, N. C., Aug. 1961.

Correspondence with Field Crop Statistics Branch, Fiber Crops and Naval Stores Section, U. S. D. A., Washington, 1960.

Correspondence with State Agricultural Stabilization and Conservation administrative officers for Ohio and Kentucky, 1960.

Cowhig, James D. and Emily O. Stewart. The Older Farm Family and Medical Costs. Agricultural Marketing Service, U. S. D. A., Agr. Inf. Bull. 235. Washington: G. P. O., 1960.

Grove, Emest W. "Per Capita Income by Economic Class of Farm, 1949," Agricultural Economics Research, VIII, No. 2. Apr. 1956.

Hagood, Margaret Jarman, Gladys K. Bowles, and Robert R. Mount. Farm-Operator Family Level-of-Living Indexes for Counties of the United States, 1945, 1950 and 1954. Agricultural Marketing Service, U. S. D. A., Statistical Bull. 204. Washington: G. P. O., 1957.

Hagood, Margaret Jarman and Daniel O. Price. Statistics for Sociologists, Rev. Ed. New York: Henry Holt and Company, 1952.

Henderson, Harry W. Price Programs. Information Division Commodity Stabilization Service, U. S. D. A., Agri. Inf. Bull. 135. Washington: G. P. O., 1957.

Loomis, Charles P. and J. Allan Bieglle. Rural Social Systems. New York: Prentice Hall, Inc., 1950.

Loomis, Charles P. Social Systems, Essays on their Persistence and Change. New York: D. Van Nostrand Company, 1960.

Pedersen, Harold A. "Cultural Differences in the Acceptance of Recommended Practices," Rural Soc., XVI, No. 1. March 1951.

Public Health Service, Federal Security Agency, National Office of Vital Statistics. State and Regional Life Tables, 1939-41. Washington: G. P. O., 1948.

Robinson, K. L. "Possible Effects of Eliminating Direct Price Support and Acreage Control Programs," Farm Economics. Dept. Agr. Econ., N. Y. State Coll. of Agr., Cornell Univ., No. 218. Oct. 1960.

Schloss, Samuel and Carol Joy Hobson. "Statistics of State School Systems; 1957-58, Organization, Staff, Pupils, and Finances," Biennial Survey of Education in the United States, 1956-58. Chap. 2. Office of Education, U. S. Dept. Health, Education and Welfare, OE-20020-58. Washington: G. P. O., 1961.

Shepherd, Geoffrey, Arnold Paulsen, Francis Kutish, Don Kaldor, Richard Heifner, and Gene Futrell. Production, Price and Income Estimates and Projections for the Feed-Livestock Economy under Specified Control and MarketClearing Conditions. Dept. Econ. and Soc., Center for Agr. and Econ. Adj., Iowa State Univ., Special Rep. 27. Ames, Iowa, Aug. 1960.

State of W. Va., Legislative Interim Comm. A Survey of the Educational Programs of the West Virginia Public Schools. The Survey Staff, E. K. Feaster, Dir., 1957. 
State Soil Conservation Committee, W. Va. Cons. Needs Comm. West Virginia Soil and Water Conservation Needs Inventory. 1961.

Strand, Edwin G., Earl O. Heady, and James A. Seagraves. Productivity of Resources Used on Commercial Farms. U. S. D. A. in cooperation with Iowa Agr. Exp. Sta., Tech. Bull. 1128. Washington: G. P. O., 1955.

U. S. Bureau of the Census. Eighteenth Census of the United States: 1960. Population, Vol. II. Washington: G. P. O., 1962.

United States Census of Agriculture: 1945. Washington: G. P. O., 1946. United States Census of Agriculture: 1954. Washington: G. P. O., 1956. United States Census of Agriculture: 1959. Washington: G. P. O., 1961.

U. S. Congress. Economic Policies for Agriculture in the 1960's. 86th Congress, 2nd Session, Joint Economic Committee Print. Washington: G. P. O., 1960.

U. S. Congress, Senate. Report from the U. S. Department of Agriculture and a Statement from the Land Grant Colleges IRM-I Advisory Committee on Farm Price and Income Projections 1960-65 under Conditions Approximating Free Production and Marketing of Agricultural Commodities. 86th Congress, 2nd Session, Senate Doc. 77. Washington: G. P. O., 1960.

U. S. Congress, Senate. The Timber Resources of West Virginia and a Report on the National Forests of West Virginia. Reports prepared by the Forest Service, U. S. D. A., Senate Doc. 33, 87 th Congress, 1st Session, presented by Mr. Byrd of W. Va. Washington: G. P. O., 1962.

U. S. Department of Agriculture, Agr. Mar. Ser., Crop Reporting Board. "Number of Farms by States 1910-56, Revised Estimates." SpSy 3(57). Washington: G. P. O., 1957.

Agr. Mar. Ser. "State Estimates of Farm Income, 1949-59, A Supplement to the July issue of The Farm Income Situation." FIS-179 (Supplement). Washington: G. P. O., 1960.

Agr. Res. Ser.-Agr. Mar. Ser. Agricultural Price and Cost Projections (for official use only). Washington: G. P. O., 1957.

Agricultural Statistics, 1959. Washington: G. P. O., 1960.

Agricultural Statistics, 1960. Washington: G. P. O., 1961.

Agr. Mar. Ser. Annual Report on Tobacco Statistics, 1959. Stat. Bull. 260. Washington: G. P. O., 1960.

Development of Agriculture's Human Resources: A Report of Low-Income

Farmers. Washington: G. P. O., 1955.

Econ. Res. Ser. Farm Real Estate Developments. CD-61. Washington: G. P. O., 1962.

Econ. Res. Ser. Farm Real Estate Taxes. RET-2. Washington: G. O. P., Oct. 1962.

Econ. Res. Ser. Farm Real Estate Market Developments. CD-63. Washington: G. P. O., Apr. 1963.

Realized Cost of Agricultural and Related Programs, by Function or Purpose, Fiscal Years 1932-1959. Washington: G. P. O., 1959.

S. C. S. Land Resource Map of West Virginia. Beltsville, Md. 1953.

Agr. Mar. Ser. The Farm Income Situation. FIS 175. Washington: G. P. O., 1959.

Agr. Mar. Ser. The Sugar Situation. Washington: G. P. O., 1957.

and U. S. Department of Commerce. Farmers' Expenditures in 1955 by Regions. U. S. D. A. Stat. Bull. No. 224. Washington: G. P. O., 1958.

Federal State Crop Reporting Service and W. Va. Department of Agriculture. West Virginia Agricultural Statistics, 1955. Charleston, W. Va.

Federal State Crop Reporting Service, Statistical Reporting Service and W. Va. Department of Agriculture. West Virginia Forest Product Market Information. Vol. 4, No. 2. Washington: G. P. O., Sept. 1963.

U. S. Department of Commerce. Statistical Abstract of the United States, 1958. Washington: G. P. O., 1959. 
U. S. Department of Health, Education and Welfare, Office of Education. Preliminary Statistics of State School Systems, 1959-1960. Circular 663. Washington: G. P. O., 1961. 




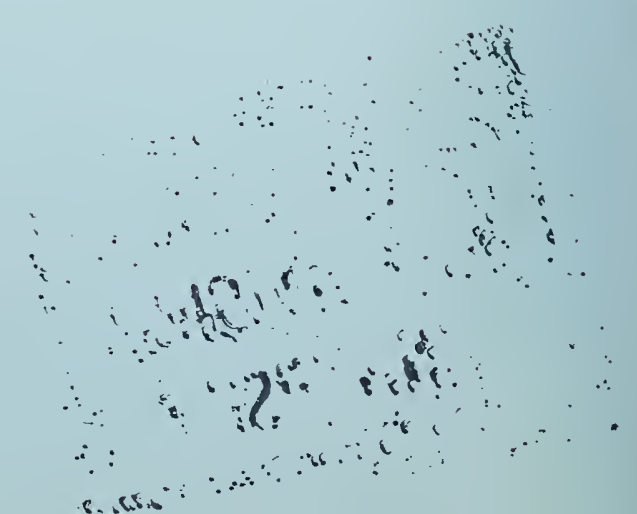



